\title{
Impacts of wildfire and post-fire land management on hydrological and sediment processes in a humid Mediterranean headwater catchment
}

Running title: Wildfire impacts on a Mediterranean catchment

João Pedro Nunes ${ }^{1,2 *}$

Léonard Bernard-Jannin ${ }^{1,2}$

María Luz Rodríguez-Blanco $2,3,4$

Anne-Karine Boulet ${ }^{2,5}$

Juliana Marisa Santos ${ }^{2}$

Jan Jacob Keizer ${ }^{2}$

1) CE3C: Centre for Ecology, Evolution and Environmental Changes, Faculdade de Ciências, Universidade de Lisboa, Portugal

2) CESAM \& Dept. Environment and Planning, University of Aveiro, Portugal

3) CICA: Centre for Advanced Scientific Research, Faculty of Sciences, University of A Coruña, Spain

4) Department of History, Art and Geography, University of Vigo, Spain

5) CERNAS: Research Centre for Natural Resources, Environment and Society, College of Agriculture, Polytechnic Institute of Coimbra, Portugal

* Corresponding author: jpcnunes@fc.ul.pt

This is the peer reviewed version of the following article:

Nunes JP, Bernard-Jannin L, Rodríguez-Blanco ML, Boulet A-K, Santos JM, Keizer JJ. 2020. Impacts of wildfire and post-fire land management on hydrological and sediment processes in a humid Mediterranean headwater catchment. Hydrological Processes, DOI: 10.1002/hyp.13926.

which has been published in final form at http://dx.doi.org/10.1002/hyp.13926. This article may be used for non-commercial purposes in accordance with Wiley Terms and Conditions for Use of SelfArchived Versions. 


\section{Impacts of wildfire and post-fire land management on hydrological and sediment processes in a humid Mediterranean headwater catchment}

João Pedro Nunes*, Léonard Bernard-Jannin, María Luz Rodríguez-Blanco, Anne-Karine Boulet, Juliana Marisa Santos, Jan Jacob Keizer

- Hydrological and sediment data was collected before and after a small wildfire in a small Mediterranean agroforestry catchment.

- Erosion was high in the burnt area when compared with croplands, especially where it was plowed for tree replanting.

- Sediment export increased, with a time lag after erosion, and most sediments came from the burnt area despite its small size.
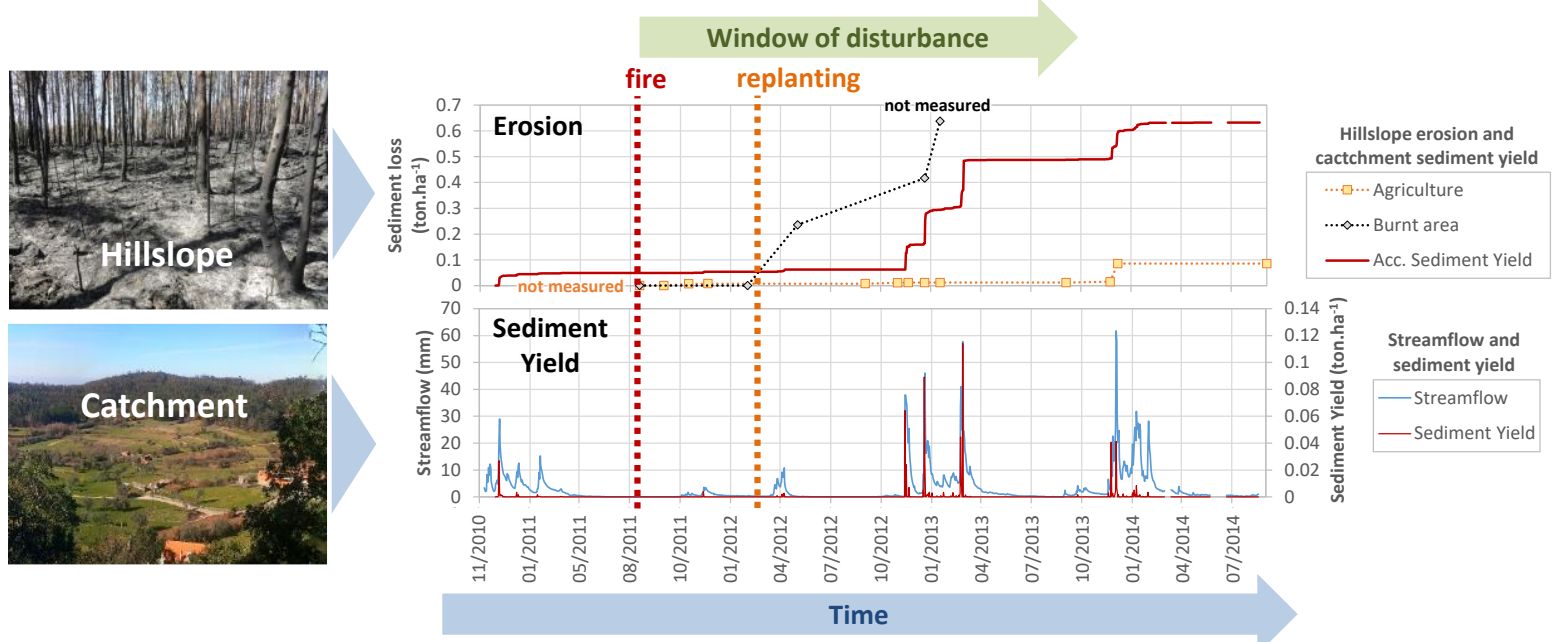


\section{Impacts of wildfire and post-fire land management on hydrological and sediment processes in a humid \\ Mediterranean headwater catchment}

João Pedro Nunes, Léonard Bernard-Jannin, María Luz Rodríguez-Blanco, Anne-Karine Boulet, Juliana Marisa Santos, Jan Jacob Keizer

\section{Abstract}

The extensive afforestation of the Mediterranean rim of Europe in recent decades has increased the number of wildfire disturbances on hydrological and sediment processes, but the impacts on headwater catchments is still poorly understood, especially when compared with the previous agricultural landscape. This work monitored an agroforestry catchment in the north-western Iberian Peninsula, with plantation forests mixed with traditional agriculture using soil conservation practices, for one year before the fire and for three years afterwards, during which period the burnt area was plowed and reforested. During this period, continuous data was collected for meteorology, streamflow and sediment concentration at the outlet, erosion features were mapped and measured after major rainfall events, and channel sediment dynamics were monitored downstream from the agricultural and the burnt forest area. Data from 202 rainfall events with over $10 \mathrm{~mm}$ was analysed in detail.

Results show that the fire led to a notable impact on sediment processes during the first two post-fire years, but not on streamflow processes; this despite the small size of the burnt area $10 \%$ of the catchment) and the occurrence of a severe drought in the first year after the fire. During this period, soil loss at the burnt forest slopes was much larger than that at most traditionally managed fields, and, ultimately, led to sediment exhaustion. At the catchment scale, storm characteristics were the dominant factor behind streamflow and sediment yield both before and after the fire. However, the data indicated a shift from detachment-limited sediment yield before the fire, to transport-limited sediment yield afterwards, with important increases in streamflow sediment concentration. This indicates that even small fires can temporarily change sediment processes in agroforestry catchments, with potential negative consequences for downstream water quality.

\section{Keywords}

Wildfire, post-fire management, hydrological response, sediment processes, Mediterranean, headwater catchment 


\section{Introduction}

In the last century, extensive land abandonment in the Mediterranean rim of Europe has led to a large increase in forested and natural areas (Pausas et al., 2008). However, the benefits of this afforestation for ecosystem services remain uncertain, as poor Mediterranean soils limit tree root development, and recurring disturbances (such as wildfires or forestry management) promote runoff and erosion (Pausas et al., 2008; Porto et al., 2009; Shakesby, 2011; Hawtree et al., 2015). There is therefore a need to further understand the impact of afforestation in this region, especially considering that climate change might have further impacts on the sustainability of Mediterranean forests and natural areas (Kovats et al., 2015) with potential consequences for hydrological processes and ecosystem services (e.g. Simonneaux et al., 2015; Carvalho-Santos et al., 2016; Rodriguez-Lloveras et al., 2016).

One of the main problems associated with this afforestation has been the increase in the number and extent of wildfire disturbances, which can negate the soil protection and regulation of water flow and quality that forests usually provide (Pausas et al., 2008; Shakesby, 2011; Carvalho-Santos et al., 2014). Runoff and soil erosion are commonly enhanced by wildfires, due to changes in vegetation cover and soil properties (Moody et al., 2013) and an increase in hydrological and sediment connectivity (Keesstra et al., 2018); exported sediments and ashes can negatively impact aquatic ecosystems (Verkaik et al., 2013) and water resources (Nunes et al., 2018b). While there has been much research on these impacts in several fire-affected regions of the globe (Moody et al., 2013), there are important differences in the main processes in each geographical region, and therefore erosion processes in Mediterranean burnt areas require a distinct research effort (Shakesby, 2011).

The north-western part of the Iberian Peninsula is an interesting case-study for this phenomenon due to the large scale of afforestation during the $20^{\text {th }}$ century with fast-growing species such as maritime pines and eucalypts (Pereira et al., 2009; Jones et al., 2011). The plantation of eucalypts led to an unexpected increase of streamflow irregularity, possibly linked with soil water repellency (Nunes et al., 2011; Ferreira et al., 2015b; Hawtree et al., 2015). However, the excellent climatic conditions of the humid Mediterranean climate led to biomass growth which, combined with human desertification and poor forest management, created conditions propitious for large and recurrent wildfires (Moreira et al., 2001; Nunes and Lourenço, 2017). These wildfires often led to severe land degradation on poor forest soils (Ferreira et al., 2008, 2015a), as has been observed for plots (Malvar et al., 2016; Prats et al., 2016; Keizer et al., 2018) and swales (Prats et al., 2019); these impacts may be compounded by post-fire forestry operations (Martins et al., 2013; Malvar et al., 2017). The fire-induced increase in sediment connectivity can to lead to impacts at the catchment scale (Fernández et al., 2020), but the lack of catchment-scale data has hampered their quantification (Ferreira et al., 2008; Keizer et al., 2015; Van Eck et al., 2016).

This quantification requires direct comparison between burnt and unburnt forest catchment conditions (either paired, or before-and-after fires), to understand the factors controlling runoff, erosion and sediment yield variability in burnt areas. The study of headwater catchments has been widely used to better understand these processes (Smetanová et al., 2018), especially through an analysis at the rainfall event scale, which allows the identification of the drivers for runoff generation, erosion and sediment yield, and how these interact between each other (Rodríguez-Blanco et al., 2010; Giménez et al., 2012; Merheb et al., 2016; Keesstra et al., 2019). Such an event-based analysis has also been successfully used to understand hydrological and sediment processes in burnt headwater catchments (Mayor et al., 2007; Moody et al., 2013; Brogan et al., 2019). However, in the Mediterranean region only a few catchment-scale studies comparing burnt and unburnt conditions have been conducted (Lavabre et al., 1993; Lavabre and Martin, 1997; Mayor et al., 2007; Stoof et al., 2012; Wu et al., 2020). Studies that compare burnt forest catchments with pre-afforestation 
agricultural catchments have not been published so far, hampering the understanding of the hydrological and erosion impacts of afforestation (and subsequent forest fires).

This knowledge gap is addressed here by presenting and analysing four years of hydrological and sediment concentration and yield data collected in a headwater catchment in north-central Portugal, where commercial forestry still coexists with traditional agricultural areas. A fire at the end of the first measurement year burned c. $10 \%$ of the catchment area, and therefore the present data set includes pre- and post-fire conditions, as well as post-fire forestry operations characteristic of this area.

\section{Material and Methods}

\subsection{Study area}

Macieira de Alcôba is a 94.4 ha headwater catchment in the Caramulo mountain range, north-central Portugal (Figure 1). It is part of the Águeda watershed which is located in the north-western Iberia pyro-region in terms of fire regime (Calheiros et al., 2020), and the western Mediterranean region in terms of hydrological and erosion response (Peña-Angulo et al., 2019). The climate of the Caramulo is humid Mediterranean and shows a strong topographic gradient for temperature and rainfall. The mean annual rainfall (2002-2015, measured in the nearby village of Pousadas) is $1850 \mathrm{~mm} \cdot \mathrm{y}^{-1}$, with a strong inter-annual variability ranging from 1112 to $2793 \mathrm{~mm} \cdot \mathrm{y}^{-1}$. The mean annual temperature is $14.4^{\circ} \mathrm{C}$ and the Penman-Monteith annual potential evapotranspiration is $1240 \mathrm{~mm} \cdot \mathrm{y}^{-1}$. There is a strong seasonal contrast: $73 \%$ of rainfall falls in a wet season in autumn and winter (lowest temperature of $8.9^{\circ} \mathrm{C}$ in January), whereas the dry season in spring and summer has $74 \%$ of the evapotranspiration demands (highest temperature of $20.6^{\circ} \mathrm{C}$ in August).
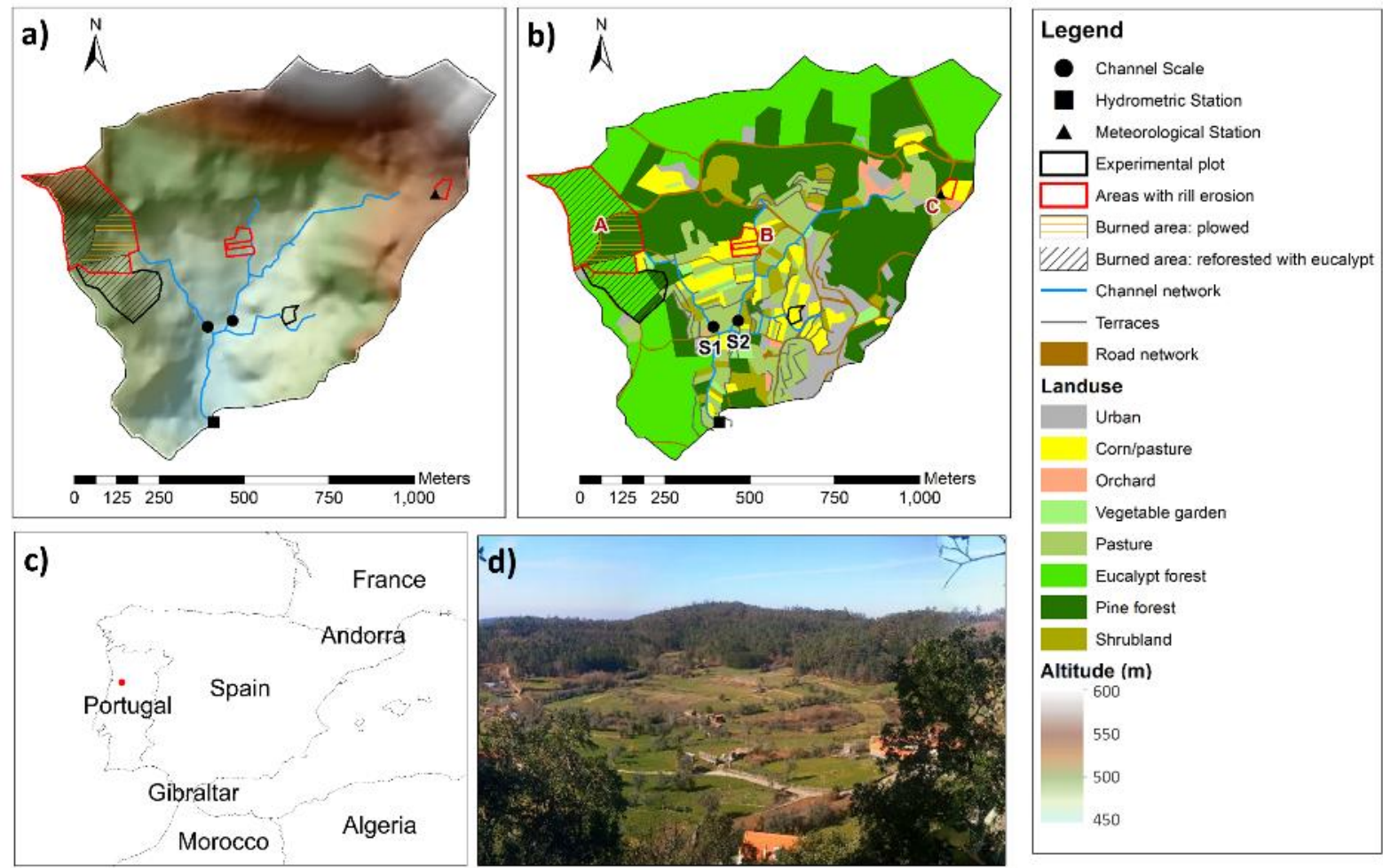

Figure 1. Measuring points overlaying a) altitude and hillshade, and b) land use; c) location of the Macieira de Alcôba catchment; and d) catchment overview picture, taken from the SE to the NW and centred in the burnt area (before the fire). 
The elevation of the catchment ranges from 441 to $620 \mathrm{~m}$ a.s.l. and its average slope is $16 \%$. The catchment is relatively compact (Figure 1a), with a Gravelius coefficient of 1.25 (Bendjoudi and Hubert, 2002); and the concentration time (Chow et al., 1988) is estimated at 30-40 min. The stream network consists of $2.3 \mathrm{Km}$ of mostly stone-walled channels, with a mean channel slope of $11.2 \%$ and a drainage density of $2.4 \mathrm{~km} \cdot \mathrm{km}^{-2}$. Soils are generally shallow, ranging in depth from $0.2 \mathrm{~m}$ on the forested hill slopes to more than $2 \mathrm{~m}$ in the agricultural fields of the valley bottom. The main soil types are Leptosols and Cambisols (IUSS Working Group WRB, 2015) developed over schist and granite bedrocks, and characterized by a sandy-loam to loamy texture with, in the agricultural areas, a high saturated hydraulic conductivity of about $30-40 \mathrm{~mm} \cdot \mathrm{h}^{-1}$ (Nunes et al., 2018a).

The present-day land cover of the catchment mainly consists of a mixture of forest (60\%) and agricultural fields (35\%) but includes the developed area of the Macieira de Alcôba village (Figure 1). The forests occupy the upper, hilly part of the catchment, and consist of plantations of eucalypts and maritime pines in about equal proportions, which is representative of the afforestation that took over most of the Águeda watershed since the 1930s (Hawtree et al., 2015). Agricultural fields occupy the lower, central part, and are typically small and often delimited by terraces and grass strips; they represent the traditional agriculture that existed throughout the Águeda watershed before afforestation (Nunes et al., 2018a). Roughly two thirds of the agricultural fields are covered by permanent pasture, and the remainder have a rotation of pasture in winter and corn in summer, with irrigation throughout the year through a complex canal network covering the entire area. Rotation plots are plowed with a mouldboard in early autumn before pasture seeding, leaving them uncovered and vulnerable to erosion during autumn and early winter, until pasture growth is sufficient to cover the soil (Nunes et al., 2018a); afterwards, growth continues throughout the wet season and pasture is harvested several times but not grazed. The final harvest is done in late spring, when the plot is again plowed in preparation for corn seeding.

A wildfire occurred in the study area in August 11 2011, burning 7.8 ha of mostly eucalypt plantations in the north-western corner of the catchment (Figure 1, Figure 2) with moderate to severe burn severity as assessed from burnt vegetation and the soil organic layer (Figure 2a and e) following Keeley (2009). These wildfires are common in the region, and parts of the Macieira catchment have previously burned in 1969, 1986 and 1991 (Ferreira, 1997). As is common practice, the burnt area was then logged during the next few months using chainsaws; most of the burnt canopy was cut and removed with tractors which left some skid trails. In early 2012, most of the burnt eucalypt area (about $80 \%$ ) was replanted with eucalypts, while most of the burnt pine area (about 20\%) was rip-plowed using a chisel plow and replanted with oaks, leaving little ground cover (Figure 1, Figure $2 b$ and f). While soil water repellency was not measured, it is common in both unburnt and burnt forest stands in this region during dry periods (Nunes et al., 2016).

The Águeda region has a large body of research since the 1980s. This includes work on forest hydrology (Leighton-Boyce et al., 2005, 2007; Boulet et al., 2015; Hawtree et al., 2015; Santos et al., 2016), the impacts of fires on hydrological and erosion processes (Shakesby et al., 1996; Ferreira, 1997; Ferreira et al., 2008; Häusler et al., 2018), hydrological modelling (Tavares Wahren et al., 2016; Nunes et al., 2018c; Pastor et al., 2019), and some research on agricultural hydrology (Nunes et al., 2018a). 

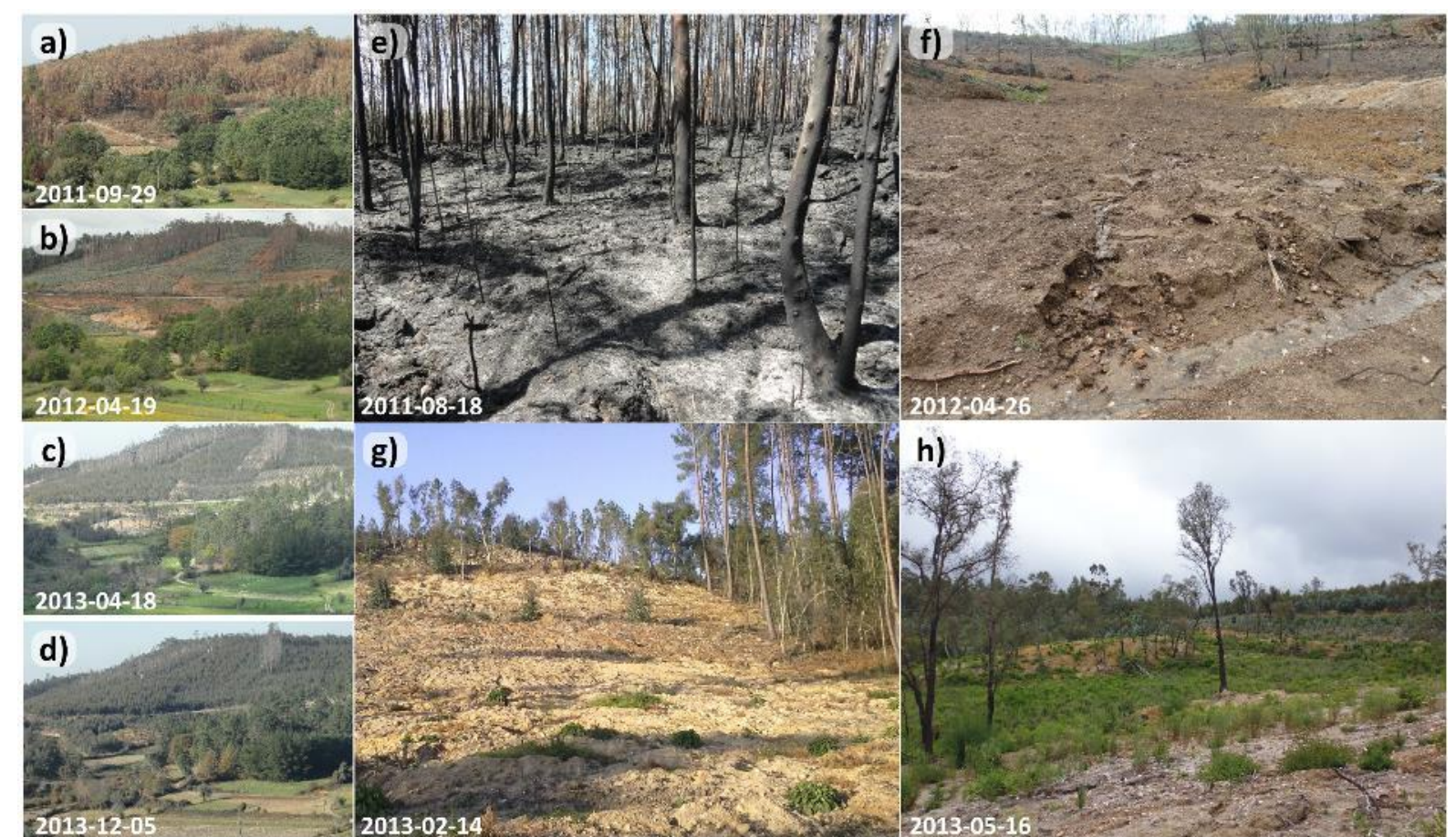

h)

Figure 2. Images of the Macieira de Alcôba watershed: overview of the burnt area a) immediately after the fire (September 2011), b) after plowing and replanting (April 2012), c) one year after replanting (April 2013) and d) in the post-fire recovery period (December 2013); and hillslope images for similar conditions, i.e. e) immediately after the fire (August 2011), f) after plowing and replanting (April 2012), g) one year after replanting (February 2013) and h) in the post-fire recovery period (May 2013).

\subsection{Data collection}

Hydrological and soil erosion processes in the Macieira de Alcôba catchment were monitored between November 92010 and September 18 2014, comprising almost four entire hydrological years (which begin at the onset of the wet season, on October 1). A parallel study was conducted in an experimental agricultural plot (Figure 1a and b) between November 2010 and May 2012, measuring soil moisture, vegetation height, surface runoff and sediment yield; the results are reported by Nunes et al. (2018a).

An automated meteorological station was installed in the catchment to record rainfall at $0.2 \mathrm{~mm}$ increments, compared with a nearby rainfall totalizer each 1-2 weeks. Intensity-Duration-Frequency curves were calculated by interpolating the parameters from the 3 closest raingauges (Brandão et al., 2001); they were then used to calculate the return period of each event (Koutsoyiannis et al., 1998). At the catchment outlet, water level was recorded at 2 min intervals using a pressure probe (CS450, Campbell Scientific) and stream discharge was then computed with the stage-discharge curve derived from 46 discharge measurements $\left(r^{2}=0.92\right)$, made each 1-2 weeks or during streamflow events with a current meter. Turbidity was recorded simultaneously (starting 3 weeks after streamflow, in November 29) with an optical sensor (OBS-3+, Campbell Scientific), filtered to remove the effects of air bubbles and algae accumulation as described in the manual. Sediment concentration was calculated from turbidity using a laboratory calibration as described in the manual, using 6 sediment samples from the channel to test a range of 65 different concentrations $\left(r^{2}=0.98\right)$; this approach is useful when logistical constraints limit taking samples during events, as it is important to ensure that a wide range of turbidity-concentration pairs are assessed (Rasmussen et al., 2009). A 2-min timeseries of streamflow and sediment concentration was therefore available for most of the period; 
battery problems led to data gaps in 2014: 13 days in spring (April) and 31 days in summer (late June and July), leading to the loss of data for, respectively, 3 and 4 rainfall events with more than $10 \mathrm{~mm}$.

Erosion features were mapped and characterized at the scale of individual fields by repeated surveys across the entire catchment, following the methodology proposed by Rodríguez-Blanco et al. (2013). This was done after large rainfall events and took place at 9 occasions between November 2011 and January 2014. Rills were identified and soil loss was quantified from the volume of eroded sediments (based on measurements of cross-sectional area every 1-2 meters, except in the burnt areas after 2013, where they were done every 5 meters) and their bulk density (based on in-situ samples). After March 2013, rills in the burnt area had merged to the extent that they could no longer be surveyed individually, and surface cover continued to be low (Figure $2 \mathrm{~g}$ ). Images of the rills are available as supplementary material.

Sediment dynamics within the channel network were monitored by means of vertical measuring scales at two locations in the permanent streams (S1 and S2 in Figure 1b). Scale S1 was located downstream of a mostly forested area where the 2011 fire occurred (drained area of 23 ha), while scale S2 was located downstream of an area of around 45 ha of which $1 / 3^{\text {rd }}$ was agricultural fields including those croplands where the bulk of rilling were observed. The measuring scales were installed at a single point on the channel, and sediment accumulation near the scale was monitored after large events.

Vegetation dynamics were characterized using 34 USGS Landsat-5, 7 and 8 images collected for the study period, with several images for most seasons. Images were radiometrically corrected and the Normalized Differential Vegetation Index (NDVI) was calculated following Van Eck et al. (2016); while the index measures vegetation greenness, it is also indicative of both canopy and ground vegetation cover in burnt areas. A Savitzky-Golay filter (Chen et al., 2004) was used to reconstruct a daily NDVI time series for the entire sampling period, also smoothing the impact of different image acquisition characteristics in the process.

\subsection{Data analysis}

Hydrological and sediment transport processes were first analysed for the entire time series, comparing daily rainfall, streamflow and sediment yield, with the data collected after major events for hillslope erosion and sediment accumulation in streams. An in-depth analysis was then performed for the catchment-scale data for the individual rainfall events with over $10 \mathrm{~mm}$ rainfall, separated by rainless periods of at least 3 hours. Each rainfall event was then linked to a single storm event, for which streamflow was separated into stormflow and baseflow using a digital filter method (Arnold et al., 1995), and the start and end of the stormflow were used to define the individual storm events. The event-based analysis focused on variables related to rainfall, streamflow, sediment yield and vegetation cover listed in the second column of Table 1 . These were selected from a larger set, excluding one or more highly correlated variables (Table 1, fourth column). The relationship between the initial variables was assessed using Pearson correlation coefficients, Principal Component Analysis (PCA), and scatterplots, using the R software (Everitt and Hothorn, 2011). The seven largest storm events were selected for a comparison of hyetographs, hydrographs and sedigraphs, and an assessment of sediment sources through the analysis of hysteresis loops in streamflow vs. sediment concentration relationships (Rodríguez-Blanco et al., 2010; Lloyd et al., 2016; Keesstra et al., 2019). Hysteresis was also quantified for all storms using the index described by Lloyd et al. (2016). 
Table 1. Variables included in and excluded from the event-based analysis.

\begin{tabular}{|c|c|c|c|}
\hline Group & Name & Description & $\begin{array}{l}\text { Related variables, excluded from the event-based } \\
\text { analysis }\end{array}$ \\
\hline \multirow[t]{4}{*}{ Rainfall } & PPtot & Total rainfall & \\
\hline & PPI30 & Peak 30min rainfall intensity & Total rainfall intensity, peak 5 min rainfall intensity \\
\hline & PPtime & Rainfall duration & \\
\hline & PPant & Antecedent Precipitation Index ${ }^{a}$ & $\begin{array}{l}\text { Antecedent precipitation for } 1 \text { day, } 2 \text { days, and so on } \\
\text { until } 10 \text { days }\end{array}$ \\
\hline \multirow[t]{6}{*}{ Streamflow } & Qtot & Total streamflow & \\
\hline & Qi & Initial streamflow & \\
\hline & Qmax & Peak 2 min streamflow & Peak 15 min streamflow, peak 2 min stormflow \\
\hline & Qbase & Baseflow fraction (of streamflow) & Baseflow, stormflow \\
\hline & $\mathrm{Q} / \mathrm{PP}$ & $\begin{array}{l}\text { Stormflow generation ratio (fraction of } \\
\text { rainfall) }\end{array}$ & Streamflow generation ratio \\
\hline & Qtime & Time to peak streamflow & Stormflow duration, time to stormflow start \\
\hline \multirow[t]{3}{*}{ Sediment } & Syield & Sediment yield & \\
\hline & Shyst & Sediment-Streamflow Hysteresis Index ${ }^{b}$ & \\
\hline & Sconc & Sediment concentration & $\begin{array}{l}\text { Peak sediment concentration, sediment concentration } \\
\text { in stormflow }\end{array}$ \\
\hline \multirow[t]{2}{*}{ Vegetation } & Vfire & $\begin{array}{l}\text { NDVI difference between burnt and } \\
\text { unburnt areas }\end{array}$ & \\
\hline & Vagri & $\begin{array}{l}\text { NDVI in agricultural areas } \\
\text { (corn/pasture rotation) }\end{array}$ & \\
\hline \multicolumn{4}{|c|}{ a) Koehler and Linsley (1951) } \\
\hline \multicolumn{4}{|c|}{ b) Lloyd et al. (2016) } \\
\hline
\end{tabular}

\section{Results}

\subsection{Catchment hydrological and erosion response}

Figure 3 gives an overview of all variables measured for the Macieira de Alcôba catchment during the study period. Figure 3a shows the differences between NDVI values in burnt and unburnt forest areas. In 2010/11 (the first hydrological year) the values were very similar, corresponding to pre-fire conditions. 2011/12 showed the greatest differences due to fire and post-fire forestry operations. 2012/13 showed small differences corresponding to partial recovery, and 2013/14 showed virtually no differences, indicating full recovery. However, while vegetation recovery in the burnt eucalypt area was due to fast tree growth (Figure $2 \mathrm{c}$ and d), recovery in the burnt and plowed area was mainly due to shrubs, as trees (both oaks and pines) were still in their initial growth stages and had small canopies (Figure $2 \mathrm{~h}$ ). Vegetation cover in crop fields mostly showed a spring peak for pasture and a summer peak for corn, typical for this area (Nunes et al., 2018a).

There were marked rainfall differences between these years, as shown in Table 2 . While rainfall in the pre-fire hydrological year was average, the first post-fire year was characterized by a prolonged and severe drought event, as shown by the very low streamflow, also explaining the low sediment yield. However, both the second and third post-fire years were wetter than the previous years, with similarly high values of rainfall and streamflow; this was due to a combination of more rain days with a small number of days with a very high rainfall (Figure $3 \mathrm{~b}$ ). In contrast, these two years differed markedly in sediment yield, which in the second post-fire year was about 3 times higher than in the third. This peak in post-fire sediment yield was almost nine times higher than the pre-fire sediment yield. 


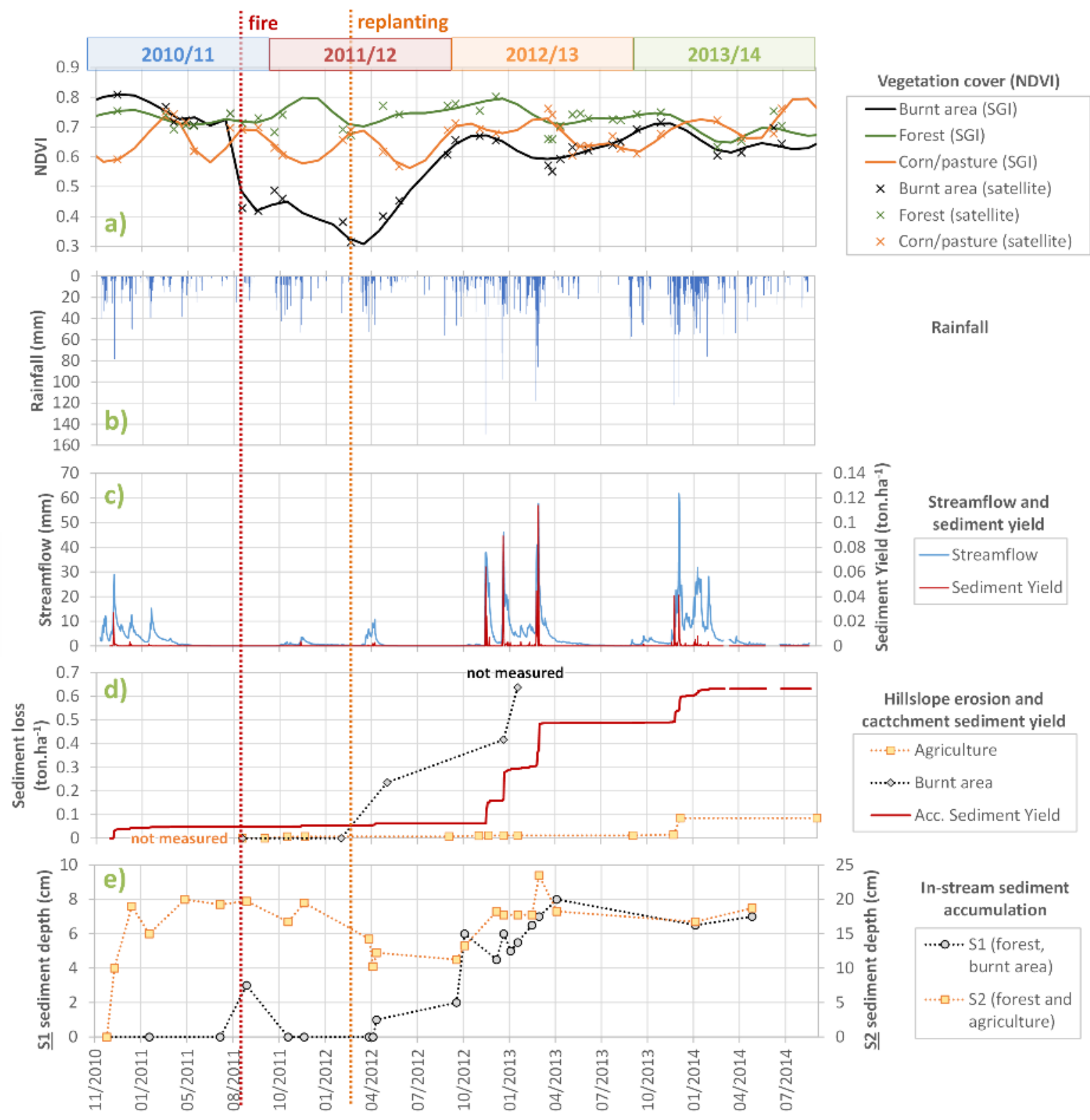

Figure 3. Overview of measurements in Macieira de Alcôba: a) vegetation cover (NDVI), both from the original satellite and the Savitsky-Golay Interpolation (SGI); b) daily rainfall, calculated from $0.2 \mathrm{~m}$ breakpoint data; c) daily streamflow and sediment yield at the outlet, calculated from 2 min continuous measurements; d) erosion measured after major events (per catchment area) compared with the cumulative daily sediment yield at the outlet (also calculated from 2 min measurement); and e) sediment accumulation in the stream bed measured after major events, for the points shown in Figure 1 (note the separate Y-axes). The top of the figure also indicates the hydrological years, and the dates of occurrence of the fire and the burnt area plowing. Instrument location is shown in Figure 1.

Figure $3 \mathrm{~b}$ and $\mathrm{c}$ show daily rainfall, streamflow and sediment yield. Despite the relatively high annual rainfall rates in the region, it still presented a clear seasonal pattern divided into a wet and dry season. Streamflow response tended to follow rainfall patterns, also with a wet and dry season, except during the first post-fire year (2011/12). Probably due to the abnormally dry catchment conditions, streamflow response was very low even following days with more than $50 \mathrm{~mm}$ of rainfall. The occurrence of sediment yield followed that of streamflow, but with a stronger response in the second 
post-fire year (2012/13) than in the pre-fire year (2010/11) or the third post-fire year (2013/14). Daily peaks in sediment yields occurred throughout the wet season of the second post-fire year, while during the pre-fire and third post-fire year they only occurred at the start of the wet season.

Table 2. Annual rainfall, streamflow and sediment yield for the measuring period; and characteristics (median and interquartile range) of important rainfall events (rainfall above $10 \mathrm{~mm}$ ) for the variables listed in Table 1, per measurement year. Variable names are described in Table 1.

\begin{tabular}{|c|c|c|c|c|}
\hline & $\begin{array}{c}2010 / 11^{a} \\
\text { pre-fire }\end{array}$ & $\begin{array}{c}2011 / 12 \\
\text { post-fire (disturbed) }\end{array}$ & $\begin{array}{c}2012 / 13 \\
\text { post-fire (disturbed) }\end{array}$ & $\begin{array}{c}2013 / 14^{b} \\
\text { post-fire (recovered) }\end{array}$ \\
\hline \multicolumn{5}{|l|}{ Annual totals: } \\
\hline Rainfall (mm) & 1616 & 1277 & 2374 & 2737 \\
\hline Streamflow (mm) & 834 & 257 & 1523 & 1575 \\
\hline Streamflow / Rainfall & 0.52 & 0.20 & 0.64 & 0.58 \\
\hline Sediment Yield (ton. ha-1) & 0.05 & 0.01 & 0.43 & 0.14 \\
\hline SY / Rainfall (kg.ha-1 $\cdot \mathrm{mm}^{-1}$ ) & 0.03 & 0.01 & 0.18 & 0.05 \\
\hline No. rainfall events $>10 \mathrm{~mm}^{\mathrm{c}}$ & 34 & 40 & 55 & 73 \\
\hline \multicolumn{5}{|c|}{ Event medians and interquartile ranges: } \\
\hline PPtot $(\mathrm{mm})$ & $\begin{array}{c}22 \\
\text { (14 to } 34)\end{array}$ & $\begin{array}{c}24 \\
\text { (14 to } 36)\end{array}$ & $\begin{array}{c}21 \\
\text { (16 to } 36)\end{array}$ & $\begin{array}{c}21 \\
\text { (14 to } 41)\end{array}$ \\
\hline $\mathrm{PPI} 30\left(\mathrm{~mm} \cdot \mathrm{h}^{-1}\right)$ & $\begin{array}{c}11 \\
\text { (7 to } 15)\end{array}$ & $\begin{array}{c}10 \\
\text { (6 to } 15)\end{array}$ & $\begin{array}{c}9 \\
\text { (6 to } 13)\end{array}$ & $\begin{array}{c}9 \\
\text { (6 to } 13)\end{array}$ \\
\hline PPtime (hr) & $\begin{array}{c}9 \\
\text { (6 to } 14)\end{array}$ & $\begin{array}{c}11 \\
\text { (8 to } 18)\end{array}$ & $\begin{array}{c}11 \\
\text { (7 to } 18)\end{array}$ & $\begin{array}{c}12 \\
\text { (8 to } 19)\end{array}$ \\
\hline PPant & $\begin{array}{c}20 \\
\text { (9 to } 37)\end{array}$ & $\begin{array}{c}24 \\
\text { (6 to } 35)\end{array}$ & $\begin{array}{c}23 \\
\text { (13 to } 60)\end{array}$ & $\begin{array}{c}32 \\
\text { (11 to } 73)\end{array}$ \\
\hline Qtot $(\mathrm{mm})$ & $\begin{array}{c}6 \\
\text { (1 to } 11)\end{array}$ & $\begin{array}{c}1 \\
\text { (0 to } 2)\end{array}$ & $\begin{array}{c}3 \\
\text { (1 to } 19)\end{array}$ & $\begin{array}{c}7 \\
\text { (2 to } 18)\end{array}$ \\
\hline Qi $\left(L . S^{-1}\right)$ & $\begin{array}{c}31 \\
\text { (6 to } 59)\end{array}$ & $\begin{array}{c}6 \\
\text { (1 to } 8)\end{array}$ & $\begin{array}{c}37 \\
\text { (3 to } 83)\end{array}$ & $\begin{array}{c}32 \\
\text { (9 to } 117)\end{array}$ \\
\hline $\operatorname{Qmax}\left(L . s^{-1}\right)$ & $\begin{array}{c}90 \\
\text { (16 to } 179)\end{array}$ & $\begin{array}{c}11 \\
\text { (3 to } 29)\end{array}$ & $\begin{array}{c}70 \\
\text { (11 to } 260)\end{array}$ & $\begin{array}{c}114 \\
\text { (22 to } 301)\end{array}$ \\
\hline Qbase & $\begin{array}{c}76 \% \\
\text { (65 to } 82 \%)\end{array}$ & $\begin{array}{c}70 \% \\
\text { (66 to } 79 \%)\end{array}$ & $\begin{array}{c}79 \% \\
\text { (64 to } 89 \%)\end{array}$ & $\begin{array}{c}81 \% \\
\text { (71 to } 87 \%)\end{array}$ \\
\hline $\mathrm{Q} / \mathrm{PP}$ & $\begin{array}{c}5 \% \\
\text { (1 to } 10 \%)\end{array}$ & $\begin{array}{c}1 \% \\
\text { (0 to } 2 \%)\end{array}$ & $\begin{array}{c}4 \% \\
\text { (1 to } 9 \%)\end{array}$ & $\begin{array}{c}6 \% \\
\text { (2 to } 11 \%)\end{array}$ \\
\hline Qtime (hr) & $\begin{array}{c}7 \\
\text { (4 to } 14)\end{array}$ & $\begin{array}{c}10 \\
(6 \text { to } 16)\end{array}$ & $\begin{array}{c}8 \\
\text { (6 to } 15)\end{array}$ & $\begin{array}{c}7 \\
(6 \text { to } 14)\end{array}$ \\
\hline Syield (ton.ha-1) & $\begin{array}{c}0.0001 \\
\text { (0 to } 0.0005)\end{array}$ & $\begin{array}{c}0 \\
\text { (0 to } 0.00003 \text { ) }\end{array}$ & $\begin{array}{c}0.0001 \\
\text { (0 to } 0.0023 \text { ) }\end{array}$ & $\begin{array}{c}0.0001 \\
\text { (0 to } 0.0007)\end{array}$ \\
\hline Shyst & $\begin{array}{c}0 \\
\text { (0 to } 0.11)\end{array}$ & $\begin{array}{c}0.03 \\
\text { (0 to } 0.09)\end{array}$ & $\begin{array}{c}0.03 \\
\text { (0 to } 0.17)\end{array}$ & $\begin{array}{c}0.09 \\
\text { (0 to } 0.17)\end{array}$ \\
\hline Sconc $\left(\mathrm{g} \cdot \mathrm{L}^{-1}\right)$ & $\begin{array}{c}0.001 \\
\text { (0 to } 0.003)\end{array}$ & $\begin{array}{c}0.0001 \\
\text { (0 to } 0.002)\end{array}$ & $\begin{array}{c}0.005 \\
\text { (0.001 to } 0.014)\end{array}$ & $\begin{array}{c}0.002 \\
\text { (0.000 to } 0.005)\end{array}$ \\
\hline Vfire & $\begin{array}{c}-0.04 \\
(-0.05 \text { to }-0.04)\end{array}$ & $\begin{array}{c}0.35 \\
\text { (0.27 to } 0.38)\end{array}$ & $\begin{array}{c}0.12 \\
\text { (0.09 to } 0.17)\end{array}$ & $\begin{array}{c}0.04 \\
(0.03 \text { to } 0.05)\end{array}$ \\
\hline Vagri & $\begin{array}{c}0.62 \\
\text { (0.59 to } 0.69)\end{array}$ & $\begin{array}{c}0.61 \\
\text { (0.59 to } 0.68)\end{array}$ & $\begin{array}{c}0.69 \\
\text { (0.68 to } 0.71)\end{array}$ & $\begin{array}{c}0.71 \\
\text { (0.67 to } 0.72 \text { ) }\end{array}$ \\
\hline
\end{tabular}

a) Streamflow and sediment yield data are missing for the start of the hydrological year (October 2010)

b) Streamflow and sediment yield data have gaps in spring and summer 2014

c) Some events were not recorded for the periods without streamflow and sediment yield data in 2010 and 2014 


\subsection{Sediment mobilization on hillslopes and within the stream network}

Within the catchment, rills were limited to two cultivated fields and the recently burnt forest area, as listed in Table 3 and shown in Figure 1. The two fields are part of the small area cultivated with corn and temporary pasture on the upper slopes in the catchment (the rest is forested), are not terraced, show a stronger slope than other fields, and are located in flow accumulation pathways. Evidence of sheet erosion and sediment deposition was observed in several other fields but was not measured.

Table 3. Rill erosion rate for individual measuring dates, relative to both the entire catchment area, and the affected fields and burnt slopes only (as shown in Figure 1b).

\begin{tabular}{|c|c|c|c|c|c|}
\hline \multirow[b]{3}{*}{$\begin{array}{l}\text { Measuring } \\
\text { date }\end{array}$} & \multicolumn{5}{|c|}{ Erosion (ton.ha-1) } \\
\hline & \multicolumn{2}{|c|}{ Area A (burnt) } & \multirow{2}{*}{$\begin{array}{c}\text { Areas } \mathbf{B}+\mathbf{C} \text { (agriculture) } \\
\text { Catchment } \\
(94.4 \mathrm{ha})\end{array}$} & \multirow{2}{*}{$\begin{array}{c}\text { Area B } \\
\text { Affected area } \\
(0.3 \mathrm{ha})\end{array}$} & \multirow{2}{*}{$\begin{array}{c}\text { Area C } \\
\text { Affected area } \\
(0.2 \mathrm{ha})\end{array}$} \\
\hline & $\begin{array}{l}\text { Catchment } \\
\text { (94.4 ha) }\end{array}$ & $\begin{array}{c}\text { Affected area } \\
(5.8 \mathrm{ha})\end{array}$ & & & \\
\hline $15 / 11 / 2011$ & 0.000 & 0.0 & 0.006 & 2.0 & 0.0 \\
\hline $20 / 12 / 2011$ & 0.000 & 0.0 & 0.001 & 0.3 & 0.0 \\
\hline 01/03/2012 & 0.000 & 0.0 & 0.000 & 0.0 & 0.0 \\
\hline $31 / 05 / 2012$ & 0.234 & 3.8 & 0.000 & 0.0 & 0.0 \\
\hline 29/11/2012 & \multicolumn{2}{|c|}{ No apparent changes } & 0.003 & 1.1 & 0.0 \\
\hline $18 / 12 / 2012$ & \multicolumn{2}{|c|}{ No apparent changes } & 0.001 & 0.3 & 0.0 \\
\hline $17 / 01 / 2013$ & 0.181 & $10.2^{\mathrm{a}}$ & 0.000 & 0.0 & 0.0 \\
\hline $14 / 02 / 2013$ & 0.220 & $12.4^{\mathrm{a}}$ & 0.000 & 0.0 & 0.0 \\
\hline $20 / 12 / 2013$ & \multicolumn{2}{|c|}{ Not measured } & 0.003 & 1.0 & 0.0 \\
\hline 03/01/2014 & \multicolumn{2}{|c|}{ Not measured } & 0.070 & 17.0 & 5.5 \\
\hline
\end{tabular}

a) Plowed area only (1.7 ha).

The timing of hillslope erosion was different in the burnt area and cultivated fields (Table 3 ). On the cultivated fields, rills were observed each year between November and January, at the start of the winter pasture rotation cycle, when vegetation cover was low; this same temporal pattern was observed for interrill erosion in the runoff plot (Nunes et al., 2018a). Here, rill width and depth ranged between 0.07 to $0.79 \mathrm{~m}$ and 0.03 to $0.12 \mathrm{~m}$ respectively, with the ones in 03/01/2014 being much wider but not deeper.

By contrast, in the burnt area, rills were first observed in May 2012 on all slopes, after logging and replanting. The rills located in the plowed part of the burnt area lengthened in January and February 2013 (Figure 1b). Rills were shallow, with width between 0.32 to $0.72 \mathrm{~m}$ and depth between 0.15 to $0.27 \mathrm{~m}$, due to the presence of a less erodible soil layer underneath. After February 2013, individual rills could no longer be distinguished and, hence, measured due to their merging and collapsing walls, indicating exhaustion of the easily erodible topsoil layer (Figure 2g). By May 2013, vegetation recovery in this area was well apparent, likely preventing further rill development (Figure $2 \mathrm{~h}$ ).

Furthermore, the timing of rill erosion in the burnt area was not completely coincident with that of the main sediment yield events, as shown in Figure $3 \mathrm{~d}$. Despite the appearance of rills in the burnt area in the first year after the fire (2011/12), very little sediment yield was observed, probably due to the severe drought limiting the connectivity of the burnt slopes with the stream. In the second postfire year (2012/13) rill development in the burnt and plowed area coincided with the first two sediment yield events; rill development probably also occurred during the third event (as rill merging 
was observed) but was not measured. In the recovered year (2013/14), rills in the crop fields coincided with sediment yield, while rill development in the burnt area was likely prevented by sediment exhaustion and vegetation cover. It should be noted that, while rills were not measured in the pre-fire year (2010/11), Nunes et al. (2018a) observed rill formation in the agricultural runoff plot at the same time of the sediment yield event of December 6 .

The total amount of erosion produced by rills over the entire study period ( 0.72 ton.ha $\left.{ }^{-1}\right)$ was similar to the cumulative sediment yield $\left(0.63\right.$ ton. $\left.^{-1} \mathrm{a}^{-1}\right)$. The bulk (88\%) was associated with the burnt area due to its greater extent, even if cumulative rill erosion rates during the study period were of similar magnitude in both areas: rill erosion in the burnt areas was 10 ton. ha ${ }^{-1}$ when considering the entire area and 26 ton. ha ${ }^{-1}$ for the plowed area only, while in crop fields it was 22 and 6 ton. ha ${ }^{-1}$, for fields B and $C$ respectively (Table 3 and Figure 1 ).

Figure 3e shows the sediment accumulation as measured by the vertical scales in the two channel sections. Scale S2, downstream from the eroded crop fields B and C, showed an initial accumulation in late 2010, possibly an artefact of sediment disturbance during installation; and a relative stability afterwards. By contrast, scale S1, downstream from the burnt area, showed little variation until the fire occurred. There was a small change in sediment just after the fire despite little rainfall and stormflow, which might be caused by drainage of water used for firefighting or safeguarding properties. Afterwards, there was a large increase in deposited sediments $(8 \mathrm{~cm})$ from May 2012 until May 2013, which agreed well with observed upstream rill erosion and, after January 2013, as well as with observed sediment yield. Sediment levels remained mostly constant after this period. While the magnitude of changes was similar in both measuring scales, they are not directly comparable due to the different upstream drainage areas, and the possible local bias due to single point measurement.

\subsection{Event-based analysis at the catchment scale}

In total, 202 storm events with over $10 \mathrm{~mm}$ rainfall were identified during the analysis period, with the number of events per hydrological year varying strongly from 34 to 73 (Table 2). Figure 4a shows the first two components of the PCA done on these events, together explaining $52.6 \%$ of the variance. The first component is mainly associated with the event rainfall total, while the second is mainly associated with catchment wetness at the start of the event. Table 4 shows the Pearson crosscorrelation matrix for the variables linked with each event (described in Table 1); correlations between variables are also graphically depicted in the PCA loading plot (Figure 4a).

Most events had a return period under 2 years; total rainfall intensity showed a small range, with larger rainfall associated with longer storms (see PPtot and PPtime in Table 2), which is characteristic of the large-scale travelling frontal weather systems normally responsible for rainfall in this region (Santos et al., 2005). However, a few storms had 30-min rainfall intensity (PPI30) well above the interquartile range. More information on storm event properties is available as supplementary material.

The stormflow generation ratio was relatively low at $6 \%$ of rainfall, and most events were dominated by baseflow, which constituted $76 \%$ of recorded streamflow. Catchment response showed moderate time compression for streamflow and high for sediment yield (Smetanová et al., 2018): 75\% of the total rainfall, stormflow and sediment yield were produced by $48 \%, 22 \%$ and $4 \%$ of the total number of events, respectively. Of the 7 events leading to $75 \%$ of sediment yield, the first occurred in 2010/11 and had a return period under 2 years, but abnormally high PPI30 (35 mm.h $\left.{ }^{-1}\right)$; the others all had a return period over 2 years, and occurred in 2012/13 (4) and 2013/14 (2). 


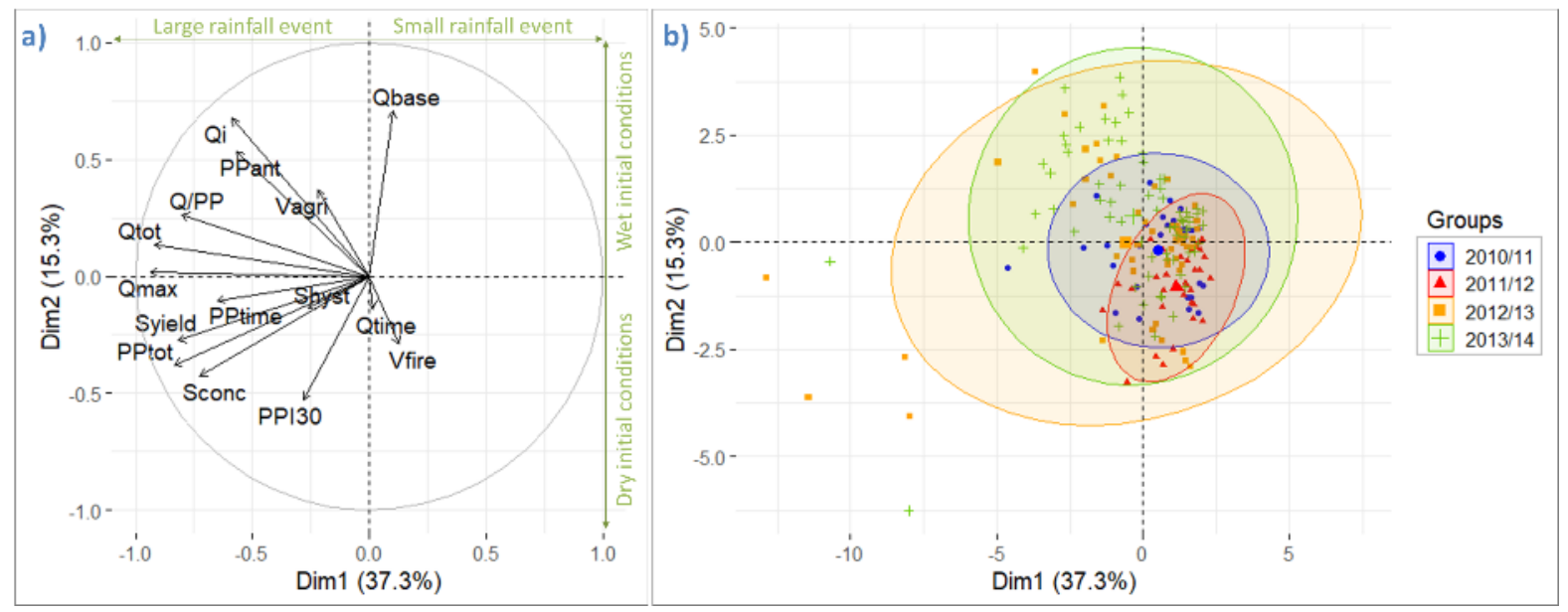

Figure 4. a) Principal Component Analysis loading plot for components 1 and 2 (Dim1 in the $x$ axis and Dim 2 in the $y$ axis, with explained variance \%), showing the variables listed in Table 1 and the component interpretation in light green (opposite to each axis); b) PCA plot for the analysed events, grouped by hydrological year, with ovals around median conditions of each year.

Table 4. Pearson cross-correlation matrix for event variables listed in Table 1, including significance. Values of $r>0.50$ are underlined, while those with $r>0.75$ are underlined and bold.

\begin{tabular}{|c|c|c|c|c|c|c|c|c|c|c|c|c|c|c|}
\hline & PPtot & PPI30 & PPtime & PPant & Qtot & Qi & Qmax & Qbase & $\mathrm{Q} / \mathrm{PP}$ & Qtime & Syield & Shyst & Sconc & Vfire \\
\hline PPant & $0.22^{*}$ & 0.04 & $0.26 * *$ & & & & & & & & & & & \\
\hline Qtot & $\underline{0.77}^{* *}$ & 0.12 & $\underline{0.61} * *$ & $\underline{0.53}^{* *}$ & & & & & & & & & & \\
\hline Qi & 0.18 & -0.05 & $0.25^{* *}$ & $\underline{0.82^{* *}}$ & $\underline{0.59}^{* *}$ & & & & & & & & & \\
\hline Qmax & $\underline{0.71}^{* *}$ & $0.25^{* *}$ & $0.49 * *$ & $\underline{0.52}^{* *}$ & $\underline{0.84}^{* *}$ & $\underline{0.56}^{* *}$ & & & & & & & & \\
\hline Q/PP & $\underline{0.53}^{* *}$ & 0.07 & $0.40^{* *}$ & $\underline{0.54}^{* *}$ & $\underline{0.82}^{* *}$ & $\underline{0.61}^{* *}$ & $\underline{0.72}^{* *}$ & 0.04 & & & & & & \\
\hline Qtime & 0.03 & -0.13 & 0.11 & -0.09 & 0.00 & -0.08 & -0.01 & -0.11 & -0.04 & & & & & \\
\hline Syield & $\underline{0.73}^{* *}$ & $0.25^{* *}$ & $0.45^{* *}$ & $0.23^{*}$ & $\underline{0.73}^{* *}$ & $0.22^{*}$ & $\underline{0.86}^{* *}$ & -0.15 & $\underline{0.52^{* *}}$ & 0.04 & & & & \\
\hline Shyst & $0.28^{* *}$ & 0.09 & $0.23^{*}$ & 0.01 & 0.17 & 0.06 & 0.15 & -0.13 & $0.23^{*}$ & -0.01 & 0.08 & & & \\
\hline Sconc & $\underline{0.67^{* *}}$ & $0.47^{* *}$ & $0.36 * *$ & 0.17 & $\underline{0.50}^{* *}$ & 0.17 & $\underline{0.74}^{* *}$ & $-0.24^{* *}$ & $0.43 * *$ & -0.01 & $\underline{0.76}^{* *}$ & $0.21^{*}$ & & \\
\hline
\end{tabular}

The inter-annual variability in median values of most rainfall characteristics (shown in Table 2) was minor. Nonetheless, events in the first post-fire year (2011/12) were clearly different from those in the other years, mostly involving small rainfall amounts and dry initial conditions (Figure $4 \mathrm{~b}$ ). These events were characterized by lower initial streamflow (Qi), reflecting drier antecedent conditions, and leading to lower stormflow generation (Q/PP), lower total and peak streamflow (Qtot, Qmax), and lower sediment concentration and yield (Sconc, Syield). Sediment concentration was clearly highest in the second post-fire year (2012/13). The difference in NDVI between burnt and unburnt vegetation 
(Vfire) revealed a sharp increase between the pre-fire year and the first post-fire year and then a gradual decrease, in accordance with the pattern in vegetation recovery discussed earlier.

Total streamflow (Qtot) was strongly correlated with rainfall total (PPtot) but practically unrelated with maximum rainfall intensity (PPI30), suggesting that stormflow generation is dominated by saturation excess overland flow processes. The same is suggested by the strong correlation of total streamflow with initial streamflow (Qi), an indicator of catchment wetness related with antecedent rainfall (PPant); and with the stormflow generation ratio (Q/PP), itself also correlated with PPtot and $\mathrm{Qi}$, but not with PPI30. This dominance of saturation-excess processes could be related with the humid climate and/or the high saturated hydraulic conductivity of the soils (Nunes et al., 2018c, 2018a).

These relationships are analysed in more detail in Figure 5a. Total streamflow appeared to approximate $50 \%$ of total rainfall when initial streamflow values were above roughly 100 L.S $^{-1}(0.4$ $\left.\mathrm{mm} \cdot \mathrm{h}^{-1}\right)$, but otherwise be well below rainfall. This threshold would therefore seem a good indicator for catchment wetness. It also helps explain the strong seasonal and inter-annual controls on stormflow generation, as initial streamflow was markedly higher during the rainy season than the dry seasons, and very low during the dry year of 2011/12 (Figure 3c).

Peak streamflow (Qmax) was well correlated with rainfall amount as well as with antecedent rainfall, total streamflow, and the stormflow generation ratio. Interestingly, the correlation with maximum rainfall intensity was not strong, which could result from the low importance of rainfall intensity for stormflow generation.

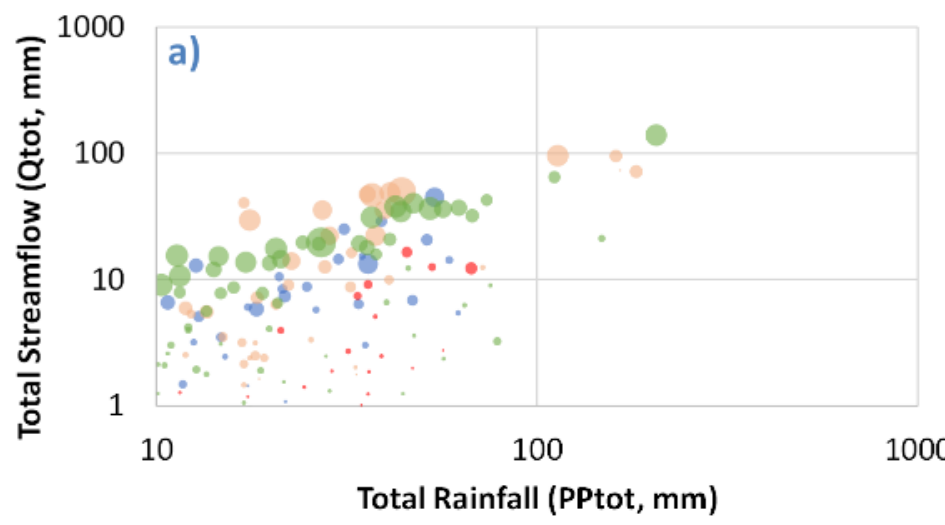

Initial Streamflow

(Qi, L.s. ${ }^{-1}$ )

- 100

- 200

300

400

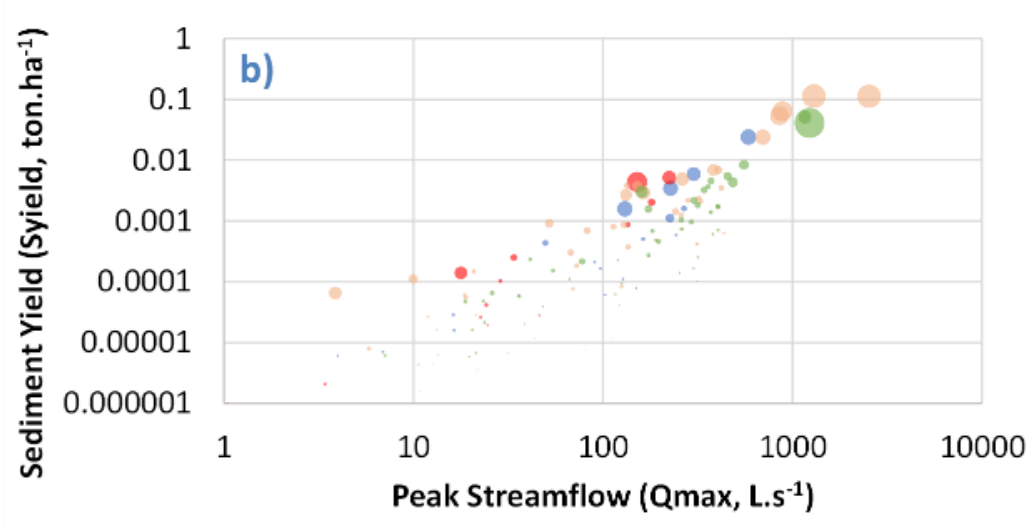

Sediment concentration (Sconc, g. $\mathrm{L}^{-1}$ )

- 0.05

0.10

0.15

0.20

Hydrological year

- 2010/11 -2011/12

$2012 / 13$-2013/14

Figure 5. Scatterplots for variables listed in Table 1, with all axes in logarithmic scale, grouped by hydrological year (Table 2): a) Ptot vs. Qtot, with circle size indicating Qi; b) Qmax vs. Syield, with circle size indicating Sconc; and c) Qmax vs. Sconc, with circle size indicating PPI30. 
For all events together, sediment concentration (Sconc) was correlated most strongly with Qmax, and, to a lesser extent, with total rainfall and total streamflow. This can indicate that concentration was limited by the transport capacity of streamflow, which is usually related with its velocity (Morgan, 2009). This Sconc-Qmax correlation was clearly stronger in the second post-fire year ( 0.86 in 2012/13) than in the remaining years (0.71, 0.63 and 0.69 in 2010/11, 2011/12 and 2013/14), which can be due to the combination of large hillslope erosion rates with more rainfall and runoff, providing a larger amount of sediment for transport (Figure 3d). Conversely, the correlation with maximum $30 \mathrm{~min}$ rainfall intensity (PPI30) was notably less important in the same year $(0.32$ in 2012/13) than in the remaining years $(0.61,0.68$ and 0.55 for 2010/11, 2011/12 and 2013/14). This indicates that detachment limitation was less important in 2011/12 than in other years, possibly due to sediment available from the burnt area, as rainfall intensity is well related with its erosive power (Morgan, 2009).

Sediment Yield (Syield) was more strongly correlated with Qmax, which probably also reflects the good correlation with sediment concentration, and can therefore also be explained by transport-limited sediment yield. There seemed to be a threshold in peak streamflow of c. $500 \mathrm{~L} . \mathrm{s}^{-1}\left(1.9 \mathrm{~mm} . \mathrm{h}^{-1}\right)$, above which both sediment concentration and yields were clearly higher (Figure 4b); below that, sediment yield was low despite variability in sediment concentration. This pattern was not impacted by the occurrence of fire. Most events had sediment hysteresis (Shyst) close to zero, indicating a close match between peak streamflow and peak sediment concentration, which can be attributed to uninterrupted sediment supply during the storm (Rodríguez-Blanco et al., 2010), and is also consistent with a limitation on sediment transport capacity.

An analysis of the top 7 events, representing $75 \%$ of sediment yield (Figure 6), shows that they presented a different behaviour than smaller events in terms of hysteresis. Most of them showed either a marked clockwise hysteresis, or little hysteresis associated with decreasing sediment concentrations for successive peak flows. Four of these events were associated to the occurrence of rill erosion features (Table 3), while such features were inferred for the other events on 6/12/2010 and 24 and 28/03/2013. Both hydrograph-sedigraph patterns generally indicate depletion of sediments during the initial stages or peaks of a storm, with sediments coming from the streams and/or from nearby hillslope sources (Rodríguez-Blanco et al., 2010; Keesstra et al., 2019), although an increasing dilution by baseflow could also play a role (Rodríguez-Blanco et al., 2010). Since the channels in the study catchment are mostly artificial, and since within-channel sediment dynamics were dominated by deposition in most of these storms (Figure 3e), the lower parts of the hillslopes are the most likely source. Given the transport limitation observed in most events (as discussed earlier), it can be postulated that the sediment not exported in smaller events (and, presumably deposited on the lower slope sections) is then exported during the major events, possibly through rill erosion. More information about these events is available as supplementary material.

The largest event, on $28 / 03 / 2013$, was an exception by revealing a counter-clockwise hysteresis. This could be linked with improved water and sediment connectivity (Keesstra et al., 2019) or with delayed sediment transport processes (Rodríguez-Blanco et al., 2010). Both explanations fit with the occurrence of bank overflow (which only occurred during this event) and associated receding floodwaters. While these conditions were unique during the study period, they produced $18 \%$ of the overall sediment yield, highlighting the important contribution of exceptional events.

Vegetation cover in the burnt area (Vfire) and the agricultural fields (Vagri) were also not well correlated with other variables. For Vfire, this could be linked with the drought in the year with the largest disturbance (2011/12) which limited hydrological response. In any case, the low relation with 
vegetation cover indicates that storm characteristics were dominant for catchment hydrological and sediment responses.
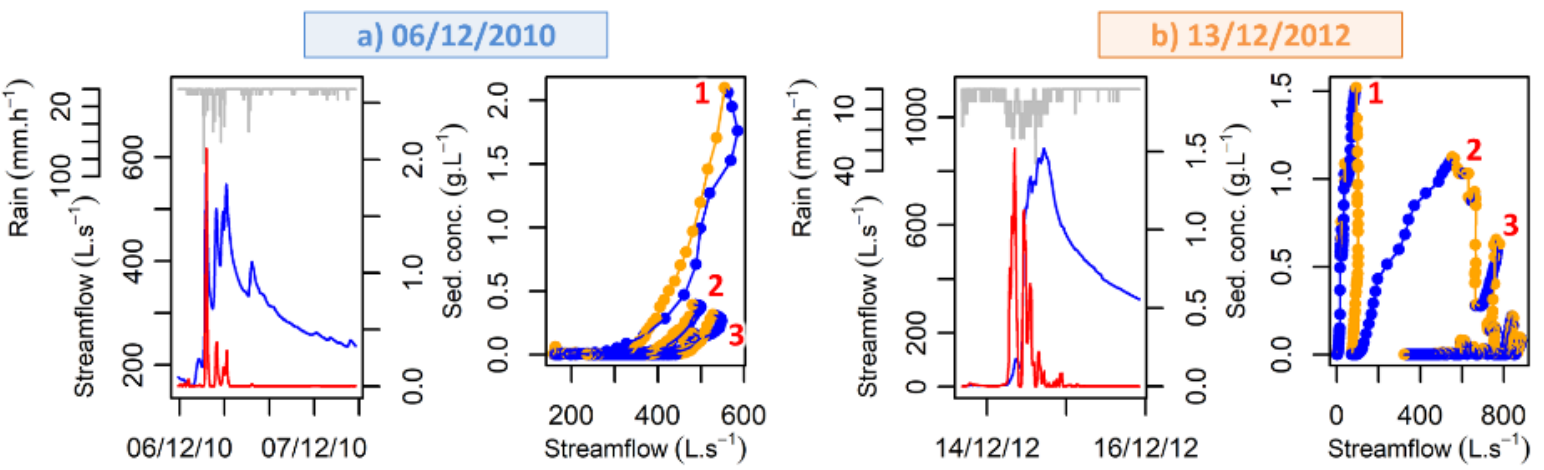

c) $17 / 01 / 2013$
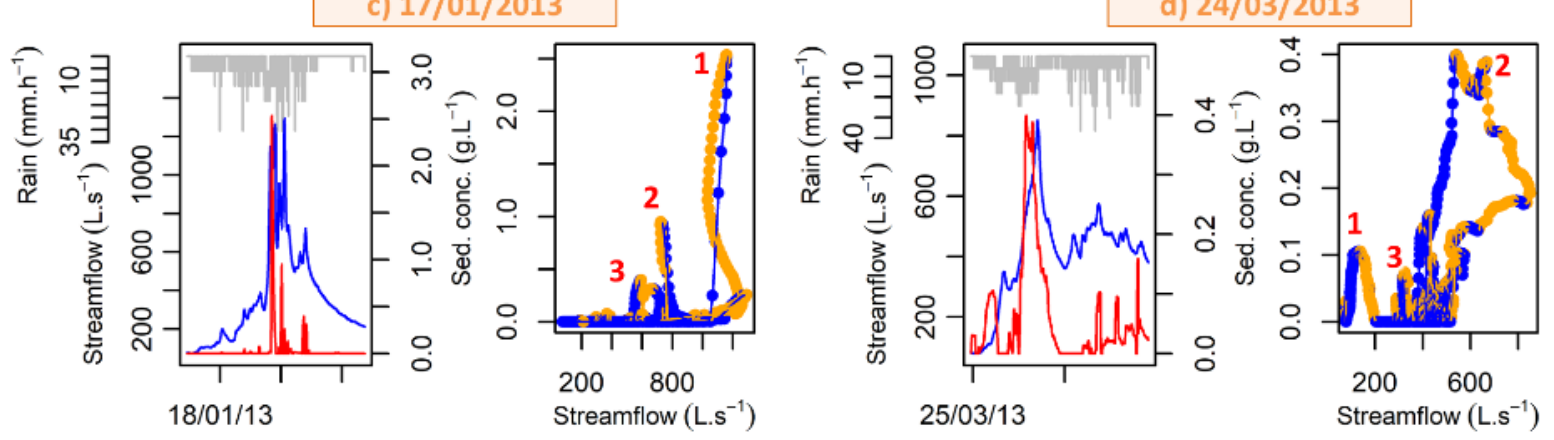

e) $28 / 03 / 2013$
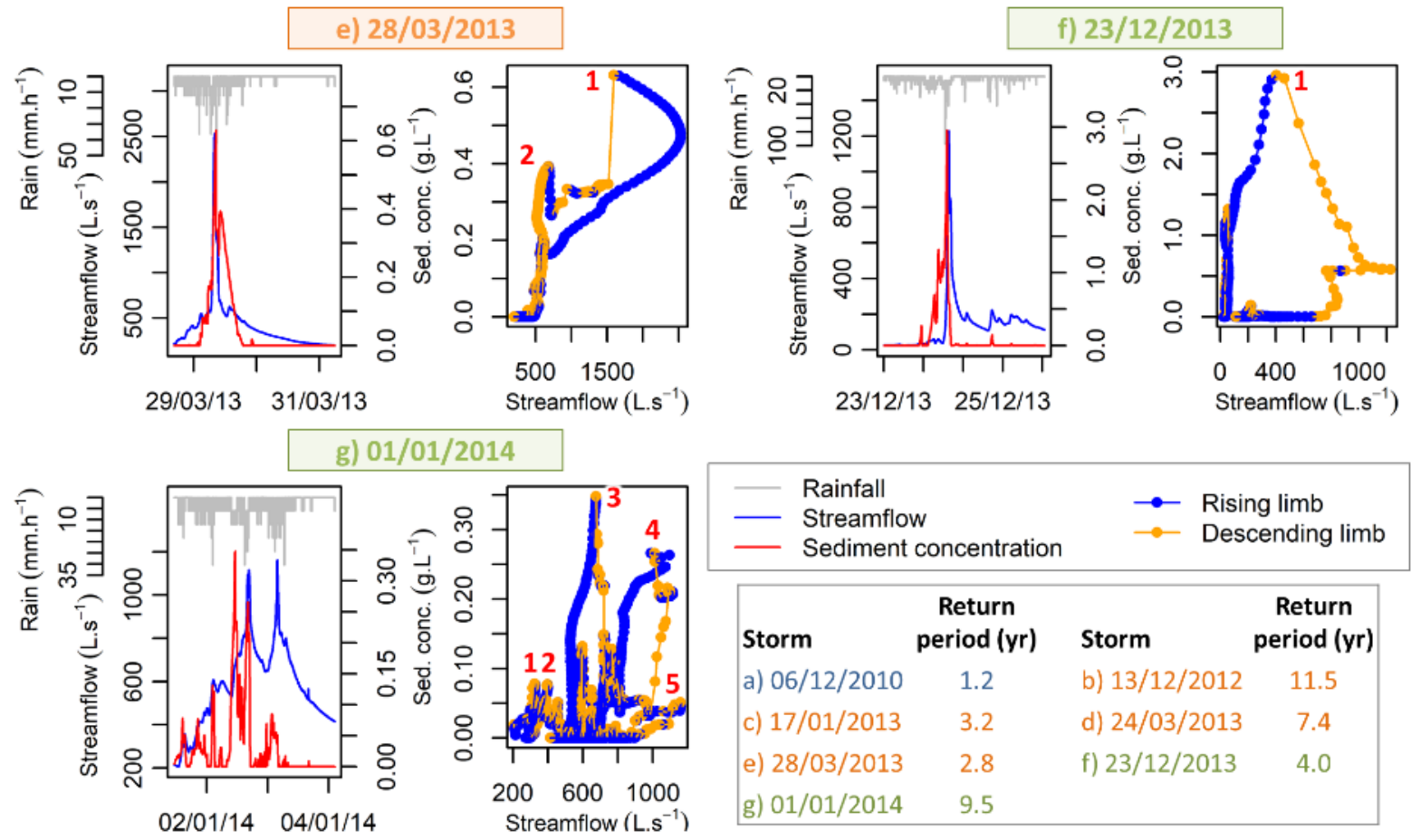

Figure 6. Detailed 2 minute streamflow and sediment concentration data for the 7 events with the highest sediment yields, including events from the pre-fire year (2010/11; a), the second post-fire disturbed year (2012/13; b to e) and the third post-fire recovered year (2013/14; $f$ and $g)$; for each event, the left panel shows the hydrograph and sedigraph while the right panel shows a plot of streamflow vs. sediment concentration, separating between the rising and descending limb of the sedigraph, with numbers indicating temporal order of occurrence within the storm. 


\section{Discussion}

\subsection{Hydrological processes}

Hydrological processes in the Macieira de Alcoba catchment presented a strong seasonal pattern, with larger streamflow occurring during the wet season due to higher rainfall amounts and wetter catchment conditions (Figure 3c, Figure 4 and Figure 5a). This seasonal response has also been observed in other Mediterranean catchments with clear wet and dry seasons (Rodríguez-Blanco et al., 2010, 2019; Giménez et al., 2012), and is usually attributed to a shift between wet and dry controls on hydrological response, with stormflow generation driven by saturation-excess in the wet season and by infiltration-excess in the dry season (Kirkby et al., 2002; Boix-Fayos et al., 2006).

This pattern was also observed in Macieira; the dominance of baseflow and the strong relationship between total event streamflow and initial streamflow indicate the predominance of saturationexcess runoff generation, while the weak relation between rainfall intensity and streamflow and the relatively low stormflow generation ratio suggest that infiltration-excess runoff generation was not important at the catchment scale (Figure 4 and Table 4). Local factors could have contributed to strengthen this effect: on one hand, infiltration-excess runoff can be limited by interception from the continuous vegetation cover in forests and agricultural soils (Valente et al., 1997; Nunes et al., 2018a) combined with the high hydraulic conductivity of agricultural and forest soils in the region (Boulet et al., 2015; Nunes et al., 2018a); and on the other, lateral flow retention by the agricultural terrace network could enhance soil saturation in crop fields (Nunes et al., 2018a).

These hydrological patterns did not appear to be affected by the fire. It is possible that fire led to an increase of surface runoff at the slope scale, as suggested by the occurrence of rill erosion in the burnt area (Figure 3d) and as observed after a previous fire in the catchment (Ferreira, 1997); this has often been observed in burnt areas, both due to the presence of soil water repellency (Malvar et al., 2016) and the degradation of soil physical structure, decreasing hydraulic conductivity (Varela et al., 2015; Ebel and Moody, 2020). However, rip-plowing might have broken the topsoil repellent layer, and limited hydrological connectivity might have prevented the effects of repellency from manifesting at the catchment scale, as observed elsewhere (Ferreira et al., 2008; Stoof et al., 2012).

Other studies in the Mediterranean have observed a post-fire increase in total and peak streamflow (Lavabre et al., 1993; Mayor et al., 2007). Several factors can explain why this was not observed in Macieira: the small size of the burnt area (Figure 1); the lower evapotranspiration of plantation forests in this region, due to low density and shallow rooting depth (Valente et al., 1997; Hawtree et al., 2015); and the fast regrowth of eucalypts after fires, leading to a fast recovery in evapotranspiration (c. 1 year; Häusler et al., 2018).

\subsection{Erosion processes}

The fire in Macieira de Alcôba had a large impact on erosion in the affected area, especially in the plowed slope (Figure $3 \mathrm{~d}$ ); and it is possible that erosion rates were limited by sediment exhaustion, before vegetation recovery was apparent (Figure 2). A compilation of plot studies ( 8 to $200 \mathrm{~m}^{2}$ ) in the Mediterranean by Shakesby (2011) reports erosion rates between 0.1 and 40 ton.ha ${ }^{-1} y^{-1}$ after high severity fires, with a median of 4 ton. ha ${ }^{-1} \mathrm{y}^{-1}$. A previous plot study $\left(16 \mathrm{~m}^{2}\right)$ in this catchment by Ferreira (1997) measured post-fire erosion rates of 2.2 ton.ha ${ }^{-1} y^{-1}$. Erosion rates observed in this study were comparable when considering the entire burnt area, despite the larger size, but higher when considering only the plowed area (Table 3).

These differences could be linked with the presence of rills in the plowed area, which is not common in Mediterranean burnt areas (Shakesby, 2011; Prats et al., 2019). While high severity fires can 
increase interill erosion by one order of magnitude (Vieira et al., 2015), erosion in the plowed area was three orders of magnitude higher than the 0.02 ton.ha ${ }^{-1} \cdot \mathrm{yr}^{-1}$ measured by Ferreira (1997) in unburnt forests. Long slope lengths (which reached up to $150 \mathrm{~m}$ in the plowed area; Figure 1a) are usually associated with lower erosion rates, unless other factors enhance rill formation, such as topographic convergence or soil properties (Prats et al., 2019); these can be enhanced by the increase in hydrological and sediment connectivity usually found in burnt catchments (Keesstra et al., 2018; López-Vicente et al., 2020). In this case, rill formation could have been enhanced by the intensive postfire management operations in the plowed area (Martins et al., 2013; Malvar et al., 2017), and their enhancement of connectivity (Martínez-Murillo and López-Vicente, 2018).

Erosion in the burnt areas was much higher than that in most agricultural areas, except for that in two agricultural fields with conditions specifically propitious for erosion (Figure $3 \mathrm{~d}$ and Table 3 ). This contrasts with other Mediterranean areas where erosion in burnt areas is smaller than that of cultivated fields (Shakesby, 2011). This can be explained by the traditional soil conservation techniques (winter pasture, terracing) still practiced in north-western lberia (Nunes et al., 2018a). Winter pastures only leave agricultural exposed to erosive rainfall for the first few months of the wet season. In the burnt area however, and especially in the plowed area, soils were exposed to erosive rainfall throughout the entire wet seasons of 2011/12 and 2012/13, which constituted the "window of disturbance" described by Shakesby (2011), thus providing more opportunities for erosive rainfall to detach sediment. As a result, while erosion in cultivated areas mostly occurred when cover was low or developing (as indicated by NDVI; Figure 3a and d), erosion in the burnt area was observed after all the largest storms. Modelling results for this study area by Nunes et al. (2018c) suggest that erosion rates in the burnt area are larger even when considering agricultural erosion for the entire pre-fire decade.

Terracing also generally leads to slope lengths below $20 \mathrm{~m}$ in agricultural fields of the Macieira catchment, limiting sediment connectivity when compared with burnt forest slopes (Nunes et al., 2018a). However, this is only true of active agriculture areas such as Macieira; in abandoned and revegetated areas common elsewhere in the Mediterranean, terrace abandonment might actually increase the connectivity after fires (Calsamiglia et al., 2017).

\subsection{Sediment yield}

The catchment scale sediment export was dominated by storm characteristics, especially peak flow rates, both before and after the fire. The bulk of the exported sediments were produced by a few large storms, which is typical of Mediterranean catchments (Smetanová et al., 2018). The amounts of sediment yield and their temporal patterns indicate that most sediments came from the burnt area (Figure 3d).

There was, however, a delay between slope-scale erosion processes and sediment export by the stream. This delay could have been caused by reduced transport capacity of the streamflow in the first year after the fire (2011/12), when streamflow was comparatively low as a result of a prolonged dry spell. In the ensuing year (2012/13) with almost twice as much rainfall, sediment concentration was noticeably higher, and sediment yield was more closely linked with peak flow than in other years (Figure 5b). While sediment export in the second post-fire year (2012/13) was also limited by streamflow transport capacity to some degree, this limitation was not evident in the largest storms when sediment depletion was observed in hysteresis curves (Figure 6). A possible explanation is that sediments deposited during smaller storms at the lower slope sections were subsequently exported at the start of larger events. 
Ferreira et al. (2008) proposed a decrease in erosion rates from hillslopes to catchments in recently burnt areas due to a decrease in sediment connectivity caused by a limited sediment transport capacity of streamflow. Lower connectivity at the catchment scale was also reported for several Mediterranean burnt catchments (Lavabre and Martin, 1997; Inbar et al., 1998; Keizer et al., 2015; López-Vicente et al., 2020; Wu et al., 2020). In Macieira, however, most of the sediments eroded by hillslope runoff processes appeared to have left the catchment within the first two years after the fire, although with a time lag between rill erosion and sediment yield (Figure $3 \mathrm{~d}$ ). This can be partly explained by the more humid climate in Macieira, as large rainfall events can increase hydrological and sediment connectivity (López-Vicente et al., 2020). In other burnt catchments, however, larger fractions of the hillslope sediments remained stored on the footslopes or in the stream network during the study periods (Inbar et al., 1998; Mayor et al., 2007; Keizer et al., 2015), possibly representing an important source of sediment following further disturbances. In any case, a better understanding of sediment connectivity in burnt areas will require substantially more case-studies than currently exist.

\subsection{Implications for the role of fires on hydrological and sediment processes}

In Macieira, the 2011 fire led to important hillslope erosion rates in the burnt area, especially where intensive post-fire management took place. These rates were similar to the largest erosion rates that were observed on the catchment's croplands on sloping terrain during an especially wet year (Table 3). This indicates that erosion in burnt eucalypt and pine forest plantations can rival the worst-case conditions for croplands, and is higher than that of traditional terraced cropping systems. The concentration of post-fire erosion in small areas and short time periods indicate that emergency stabilization approaches such as mulching (Ferreira et al., 2015a; Keizer et al., 2018) could greatly limit the immediate impacts of fire and post-fire management. Similarly, structural landscape management, e.g. with riparian vegetation, could help prevent eroded sediments from reaching the streams (Pastor et al., 2019).

In the long term, however, fire-induced erosion would only seem to be important in case of recurrent wildfires. This has not been the case in Macieira over the past 4 decades but only in the sense that the several fires that did occur affected different parts of the catchment (Ferreira, 1997). Nonetheless, Portuguese rangelands will typically burn once each 24 years (Cardoso Pereira et al., 2006), and recurrently burnt areas in this region have been reported to produce enhanced soil losses (Hosseini et al., 2016).

Streamflow and sediment yield of individual events were mainly determined by post-fire rainfall conditions, with fire occurrence playing a secondary role at most as observed elsewhere (Mayor et al., 2007; Stoof et al., 2012; Wu et al., 2020). While streamflow did not reveal any obvious impacts of the present fire, sediment yields did. The fire appeared to lead to a large increase in sediment supply, decreasing the importance of sediment limitations in favour of transport limitations, and changing sediment yield patterns. It is possible that the normal sediment yield patterns in agroforestry headwater catchments have peak sediment yields during the autumn harvest and plowing season, as observed for Macieira (Figure 3c) before the fire (2010/11) and after recovery (2013/14); a longer time-series would shed more light on this issue.

It is worth stressing that the excess in sediment supply following the fire occurred despite the relatively small size of the burnt area and a relatively high streamflow, at least during the second postfire year (2012/13). Even limited fire-induced sediment supply could have a negative impact on downstream aquatic ecosystems and organisms, as they are sensitive to the toxic compounds present in ashes and burnt topsoil (Silva et al., 2015; Campos et al., 2016; Carvalho et al., 2019). Sediments 
accumulated in stream networks, as was the case in Macieira (Figure 3e), have the potential for longterm impacts on water quality.

However, while a larger fire might lead to a larger sediment supply, it would not necessarily lead to higher sediment concentration due to lower in-stream connectivity caused by transport capacity limitations. The additional sediments (including wildfire ash) might accumulate in lower slopes and the stream bed, and be exported in subsequent years, as has been observed earlier in burnt catchments (Inbar et al., 1998; Mayor et al., 2007); or even deposit in the floodplain for larger watersheds (Wu et al., 2020). Further studies in catchments burnt to a greater extend are urgently needed to assess this.

\subsection{Limitations and future work}

This work had several limitations, some of which were already pointed out, such as the small size of the fire and the perhaps somewhat limited duration of the time series. However, there is a scarcity of catchment-scale data from burnt areas, which can be explained to a large degree by the difficulties in monitoring these infrequent and unpredictable phenomena (Shakesby, 2011; Moody et al., 2013). Despite its limitations, however, the present dataset includes a large number of storm events (202 with over $10 \mathrm{~mm}$ ) as well as storm events producing sediment yields (146). The latter figure is well above the 100 sediment-producing events that Peña-Angulo et al. (2019) proposed as a minimum. It is also much larger than the number of events that are typically recorded by studies in dryer Mediterranean areas. For example, Mayor et al. (2007) observed 31 events in six years.

Other, more minor limitations of this study were the existence of some gaps in streamflow and sediment yield, even if relatively few and of short duration (Figure 3), the limitation of erosion feature surveys to rill erosion while ignoring sheet erosion, and the reduced number of locations and times where in-stream sediment dynamics were measured.

Further work is needed to explore the role of fire for erosion, sediment transport patterns, and especially catchment-scale streamflow and sediment yield, preferably analysing catchments in the same climatic region with different burnt area sizes and characteristics, and different post-fire meteorological patterns. However, the complications associated with collecting data in burnt catchments will likely limit data availability in the future. In these conditions, sediment tracing can be used to overcome logistical constraints by mapping sediment transport in the catchment with limited samples and/or after it occurs (García-Comendador et al., 2020). Alternatively, numerical hydrological and erosion modelling could provide an interesting approach to study catchment processes, as exemplified for this catchment by Nunes et al. (2018c) and Pastor et al. (2019).

\section{Conclusions}

This work assessed the impacts of fire and post-fire land management on the hydrological and sediment response of a catchment in the western Mediterranean, in a landscape where traditional terraced crop fields are mixed with plantations forests representative of the afforestation experienced by this region in recent decades. The catchment was originally selected to study runoff and erosion processes for traditional agricultural practices but the occurrence of a fire towards the end of the first monitoring year was envisaged as an additional opportunity and the main motivation for continuing beyond the duration of the funding project.

The results indicate that fires can have a large impact on soil loss on forested hillslopes, resulting in losses comparable to those of the most vulnerable croplands, and well-above those of the majority of crop fields, especially those where traditional soil conservation measures such as winter vegetation cover and terracing are implemented. As the impact of individual fires is short-lived, the overall role 
of fire depends on its regime and, in particular its recurrence. In the study catchment, the recurrence interval is longer than is typical for Portuguese rangelands, where frequently burnt areas have been observed to show clear signs of soil degradation.

Catchment scale results did not show a noticeable impact of the fire on streamflow response but they did on the amount of sediments available for export. Storm conditions were nonetheless the dominant factors driving sediment yields, suggesting that the window-of-disturbance was limited to the first two post-fire years. Such a reduced disturbance period can be linked with the relatively small size of the burnt area, but does not preclude important impacts on aquatic habitats within and downstream of the catchment.

There results provide an insight on how sediment is detached and transported in burnt catchments, which is key to understand and prevent post-fire water contamination. The temporal lag between erosion and sediment yield and the dominance of post-fire storm characteristics are consistent with observations in other Mediterranean catchments, but additional research is needed to benchmark the present results; and it should be noted that the dominant catchment-scale processes might differ in other climatic regions.

Finally, the results suggest the importance of post-fire management operations for soil degradation and sediment exports, even in small burnt areas. This indicates that intensively managed areas should be prioritized for emergency post-fire stabilisation, and that soil conservation techniques could be developed to limit the negative impact of management.

\section{Acknowledgements}

This work was funded by the Portuguese Foundation for Science and Technology (FCT/MCTES) within the framework of project ERLAND: "Direct and indirect impacts of climate change on soil erosion and land degradation in Mediterranean watersheds" (FCOMP-01-0124-FEDER-008534), the baseline funding of the CE3C and CESAM research units (UID/BIA/00329/2019, UID/AMB/50017/2019), and the research grants attributed to J.P. Nunes (SFRH/BPD/39721/2007, SFRH/BPD/87571/2012 and IF/00586/2015) and J.J. Keizer (IF/01465/2015). The authors also acknowledge the contributions of Maria Ermitas Rial Rivas and other members of the Earth Surface Processes Team of the University of Aveiro in supporting almost four years of regular fieldwork in the Macieira de Alcôba experimental catchment.

\section{Data availability statement}

The data that support the findings of this study are available from the corresponding author upon reasonable request.

\section{References}

Arnold JG, Allen PM, Muttiah R, Bernhardt G. 1995. Automated Base Flow Separation and Recession Analysis Techniques. Ground Water 33 (6): 1010-1018 DOI: 10.1111/j.17456584.1995.tb00046.x

Bendjoudi H, Hubert P. 2002. Le coefficient de compacité de Gravelius: Analyse critique d'un indice de forme des bassins versants. Hydrological Sciences Journal 47 (6): 921-930 DOI: $10.1080 / 02626660209493000$

Boix-Fayos C, Martinez-Mena M, Arnau-Rosalen E, Calvo-Cases A, Castillo V, Albaladejo J. 2006. Measuring soil erosion by field plots: Understanding the sources of variation. Earth-Science Reviews 78 (3-4): 267-285 DOI: DOI 10.1016/j.earscirev.2006.05.005 
Boulet A-K, Prats SA, Malvar MC, González-Pelayo O, Coelho COA, Ferreira AJD, Keizer JJ. 2015. Surface and subsurface flow in eucalyptus plantations in north-central Portugal. Journal of Hydrology and Hydromechanics 63 (3): 193-200 DOI: 10.1515/johh-2015-0015

Brandão C, Rodrigues R, Pinto da Costa J. 2001. Análise de fenómenos extremos: precipitações intensas em Portugal continental. INAG - Instituto da Água, Lisbon.

Brogan DJ, Nelson PA, MacDonald LH. 2019. Spatial and temporal patterns of sediment storage and erosion following a wildfire and extreme flood. Earth Surface Dynamics 7 (2): 563-590 DOI: 10.5194/esurf-7-563-2019

Calheiros T, Nunes JP, Pereira MG. 2020. Recent evolution of spatial and temporal patterns of burnt areas and fire weather risk in the Iberian Peninsula. Agricultural and Forest Meteorology 287: 107923 DOI: 10.1016/j.agrformet.2020.107923

Calsamiglia A, Lucas-Borja ME, Fortesa J, García-Comendador J, Estrany J. 2017. Changes in soil quality and hydrological connectivity caused by the abandonment of terraces in a Mediterranean burned catchment. Forests 8 (9): 1-20 DOI: 10.3390/f8090333

Campos I, Abrantes N, Keizer JJ, Vale C, Pereira P. 2016. Major and trace elements in soils and ashes of eucalypt and pine forest plantations in Portugal following a wildfire. Science of the Total Environment 572: 1363-1376 DOI: 10.1016/j.scitotenv.2016.01.190

Cardoso Pereira JM, Brito Carreiras JM, Neves Silva JM, Vasconcelos MJ. 2006. Alguns conceitos básicos sobre os fogos rurais em Portugal. In Incêndios Florestais Em Portugal. Caracterização, Impactes e Prevenção, Pereira JS, , Cardoso Pereira JM, , Castro Rego F, , Silva JMN, , Pereira da Silva T (eds).ISAPress: Lisbon; 133-161.

Carvalho-Santos C, Honrado JP, Hein L. 2014. Hydrological services and the role of forests: Conceptualization and indicator-based analysis with an illustration at a regional scale. Ecological Complexity 20: 69-80 DOI: 10.1016/j.ecocom.2014.09.001

Carvalho-Santos C, Nunes JP, Monteiro AT, Hein L, Honrado JP. 2016. Assessing the effects of land cover and future climate conditions on the provision of hydrological services in a medium-sized watershed of Portugal. Hydrological Processes 30 (5): 720-738 DOI: 10.1002/hyp.10621

Carvalho F, Pradhan A, Abrantes N, Campos I, Keizer JJ, Cássio F, Pascoal C. 2019. Wildfire impacts on freshwater detrital food webs depend on runoff load, exposure time and burnt forest type. Science of the Total Environment 692: 691-700 DOI: 10.1016/j.scitotenv.2019.07.265

Chen J, Jönsson P, Tamura M, Gu Z, Matsushita B, Eklundh L. 2004. A simple method for reconstructing a high-quality NDVI time-series data set based on the Savitzky-Golay filter. Remote Sensing of Environment 91: 332-344 DOI: 10.1016/j.rse.2004.03.014

Chow VT, Maidment DR, Mays LW. 1988. Applied Hydrology. McGraw-Hill: New York.

Ebel BA, Moody JA. 2020. Parameter estimation for multiple post-wildfire hydrologic models. Hydrological Processes: hyp.13865 DOI: 10.1002/hyp.13865

Van Eck CM, Nunes JP, Vieira DC, Keesstra S, Keizer JJ. 2016. Physically-based modelling of the postfire runoff response of a forest catchment in central Portugal: using field vs. remote sensing based estimates of vegetation recovery. Land Degradation \& Development 27 (5): 1535-1544 DOI: $10.1002 / \mathrm{ldr} .2507$

Everitt B, Hothorn T. 2011. An Introduction to Applied Multivariate Analysis with R. Springer-Verlag: New York. DOI: 10.1007/978-1-4419-9650-3

Fernández C, Fernández-Alonso JM, Vega JA. 2020. Exploring the effect of hydrological connectivity 
and soil burn severity on sediment yield after wildfire and mulching. Land Degradation \& Development: Idr.3539 DOI: 10.1002/ldr.3539

Ferreira AJD, Coelho COA, Ritsema CJ, Boulet AK, Keizer JJ. 2008. Soil and water degradation processes in burned areas: lessons learned from a nested approach. Catena 74: 273-285 DOI: 10.1016/j.catena.2008.05.007

Ferreira AJD, Prats Alegre S, Coelho COA, Shakesby RA, Páscoa FM, Ferreira CSS, Keizer JJ, Ritsema C. 2015a. Strategies to prevent forest fires and techniques to reverse degradation processes in burned areas. Catena 128: 224-237 DOI: 10.1016/j.catena.2014.09.002

Ferreira CG. 1997. Erosão hídrica em solos florestais. Estudo em povoamentos de Pinus Pinaster e Eucalyptus Globulus em Macieira de Alcôba - Águeda. Revista da Faculdade de Letras da Universidade do Porto - Geografia I Série XII/XIII: 145-244

Ferreira CSS, Walsh RPD, Steenhuis TS, Shakesby RA, Nunes JP, Coelho COA, Ferreira AJD. 2015b. Spatiotemporal variability of hydrologic soil properties and the implications for overland flow and land management in a peri-urban Mediterranean catchment. Journal of Hydrology 525: 249-263 DOI: 10.1016/j.jhydrol.2015.03.039

García-Comendador J, Martínez-Carreras N, Fortesa J, Borràs A, Calsamiglia A, Estrany J. 2020. Analysis of post-fire suspended sediment sources by using colour parameters. Geoderma 379 (July): 114638 DOI: 10.1016/j.geoderma.2020.114638

Giménez R, Casalí J, Grande I, Díez J, Campo M, Álvarez-Mozos J, Goñi M. 2012. Factors controlling sediment export in a small agricultural watershed in Navarre (Spain). Agricultural Water Management 110: 1-8 DOI: 10.1016/j.agwat.2012.03.007

Häusler M, Nunes JP, Soares P, Sánchez JM, Silva JMN, Warneke T, Keizer JJ, Pereira JMC. 2018. Assessment of the indirect impact of wildfire (severity) on actual evapotranspiration in eucalyptus forest based on the surface energy balance estimated from remote-sensing techniques. International Journal of Remote Sensing DOI: 10.1080/01431161.2018.1460508

Hawtree D, Nunes JP, Keizer JJ, Jacinto R, Santos J, Rial-Rivas ME, Boulet A-K, Tavares-Wahren F, Feger K-H. 2015. Time series analysis of the long-term hydrologic impacts of afforestation in the Águeda watershed of north-central Portugal. Hydrology and Earth System Sciences 19 (7): 3033-3045 DOI: 10.5194/hess-19-3033-2015

Hosseini M, Keizer JJ, Gonzalez-Pelayo O, Prats SA, Ritsema C, Geissen V. 2016. Effect of fire frequency on runoff, soil erosion, and loss of organic matter at the micro-plot scale in northcentral Portugal. Geoderma 269: 126-137 DOI: 10.1016/j.geoderma.2016.02.004

Inbar M, Tamir M, Wittenberg L. 1998. Runoff and erosion processes after a forest fire in Mount Carmel, a Mediterranean area. Geomorphology 24 (1): 17-33 DOI: 10.1016/S0169$555 \times(97) 00098-6$

IUSS Working Group WRB. 2015. World reference base for soil resources 2014, update 2015. International soil classification system for naming soils and creating legends for soil maps. World Soil Resources Reports No. 106. Food and Agriculture Organization of the United Nations, Rome.

Jones N, de Graaff J, Rodrigo I, Duarte F. 2011. Historical review of land use changes in Portugal (before and after EU integration in 1986) and their implications for land degradation and conservation, with a focus on Centro and Alentejo regions. Applied Geography 31 (3): 10361048 DOI: 10.1016/j.apgeog.2011.01.024

Keeley JE. 2009. Fire intensity, fire severity and burn severity: A brief review and suggested usage. 
International Journal of Wildland Fire 18 (1): 116-126 DOI: 10.1071/WF07049

Keesstra S, Nunes JP, Saco P, Parsons T, Poeppl R, Masselink R, Cerdà A. 2018. The way forward: Can connectivity be useful to design better measuring and modelling schemes for water and sediment dynamics? Science of The Total Environment 644: 1557-1572 DOI:

10.1016/j.scitotenv.2018.06.342

Keesstra SD, Davis J, Masselink RH, Casalí J, Peeters ETHM, Dijksma R. 2019. Coupling hysteresis analysis with sediment and hydrological connectivity in three agricultural catchments in Navarre, Spain. Journal of Soils and Sediments 19 (3): 1598-1612 DOI: 10.1007/s11368-01802223-0

Keizer JJ, Martins MAS, Prats SA, Faria SR, González-Pelayo O, Machado Al, Rial-Rivas ME, Santos LF, Serpa D, Varela MET. 2015. Within-in flume sediment deposition in a forested catchment following wildfire and post-fire bench terracing, north-central Portugal. Cuadernos de Investigación Geográfica 41 (1): 149 DOI: 10.18172/cig.2700

Keizer JJ, Silva FC, Vieira DCS, González-Pelayo O, Campos I, Vieira AMD, Valente S, Prats SA. 2018. The effectiveness of two contrasting mulch application rates to reduce post-fire erosion in a Portuguese eucalypt plantation. CATENA 169: 21-30 DOI: 10.1016/J.CATENA.2018.05.029

Kirkby M, Bracken L, Reaney S. 2002. The influence of land use, soils and topography on the delivery of hillslope runoff to channels in SE Spain. Earth Surface Processes and Landforms 27 (13): 1459-1473 DOI: Doi 10.1002/Esp.441

Koehler MA, Linsley RK. 1951. Predicting the Runoff from Storm Rainfall. Research Paper no. 34. U.S. Department of Commerce, Weather Bureau, Washington.

Koutsoyiannis D, Kozonis D, Manetas A. 1998. A mathematical framework for studying rainfall intensity-duration-frequency relationships. Journal of Hydrology 206 (1-2): 118-135 DOI: 10.1016/S0022-1694(98)00097-3

Kovats RS, Valentini R, Bouwer LM, Georgopoulou E, Jacob D, Martin E, Rounsevell M, Soussana JF. 2015. Europe. In Climate Change 2014: Impacts, Adaptation and Vulnerability: Part B: Regional Aspects: Working Group II Contribution to the Fifth Assessment Report of the Intergovernmental Panel on Climate Change, , Barros VR, , Field CB, , Dokken DJ, , Mastrandrea MD, , Mach KJ, , Bilir TE, , Chatterjee M, , Ebi KL, , Estrada YO, , Genova RC, et al. (eds).Cambridge University Press: Cambridge and New York; 1267-1326. DOI: 10.1017/CBO9781107415386.003

Lavabre J, Martin C. 1997. Impact d'un incendie de forêt sur l'hydrologie et l'érosion hydrique d'un petit bassin versant méditerranéen. In Human Impact on Erosion and Sedimentation (Proceedings of Rabat Symposium S6, April 1997). IAHS Publication No. 245.39-47.

Lavabre J, Torres DS, Cernesson F. 1993. Changes in the hydrological response of a small Mediterranean basin a year after a wildfire. Journal of Hydrology 142 (1-4): 273-299 DOI: 10.1016/0022-1694(93)90014-Z

Leighton-Boyce G, Doerr SH, Shakesby RA, Walsh RPD. 2007. Quantifying the impact of soil water repellency on overland flow generation and erosion: a new approach using rainfall simulation and wetting agent on in situ soil. Hydrological Processes 21 (17): 2337-2345 DOI: 10.1002/hyp.6744

Leighton-Boyce G, Doerr SH, Shakesby RA, Walsh RPD, Ferreira AJD, Boulet A-K, Coelho COA. 2005. Temporal dynamics of water repellency and soil moisture in eucalypt plantations, Portugal. Australian Journal of Soil Research 43 (3): 269 DOI: 10.1071/SR04082

Lloyd CEM, Freer JE, Johnes PJ, Collins AL. 2016. Technical Note: Testing an improved index for 
analysing storm discharge-concentration hysteresis. Hydrology and Earth System Sciences 20 (2): 625-632 DOI: 10.5194/hess-20-625-2016

López-Vicente M, González-Romero J, Lucas-Borja ME. 2020. Forest fire effects on sediment connectivity in headwater sub-catchments: Evaluation of indices performance. Science of the Total Environment 732: 139206 DOI: 10.1016/j.scitotenv.2020.139206

Malvar MC, Prats SA, Nunes JP, Keizer JJ. 2016. Soil water repellency severity and its spatio-temporal variation in burnt eucalypt plantations in north-central Portugal. Land Degradation \& Development 27 (5): 1463-1478 DOI: 10.1002/Idr.2450

Malvar MC, Silva FC, Prats SA, Vieira DCS, Coelho COA, Keizer JJ. 2017. Short-term effects of post-fire salvage logging on runoff and soil erosion. Forest Ecology and Management 400: 555-567 DOI: 10.1016/j.foreco.2017.06.031

Martínez-Murillo JF, López-Vicente M. 2018. Effect of Salvage Logging and Check Dams on Simulated Hydrological Connectivity in a Burned Area. Land Degradation and Development 29 (3): $701-$ 712 DOI: $10.1002 /$ Idr.2735

Martins MAS, Machado AI, Serpa D, Prats SA, Faria SR, Varela MET, González-Pelayo Ó, Keizer JJ. 2013. Runoff and inter-rill erosion in a Maritime Pine and a Eucalypt plantation following wildfire and terracing in north-central Portugal. Journal of Hydrology and Hydromechanics 61 (4): 261-268 DOI: 10.2478/johh-2013-0033

Mayor AG, Bautista S, Llovet J, Bellot J. 2007. Post-fire hydrological and erosional responses of a Mediterranean landscape: Seven years of catchment-scale dynamics. Catena 71 (1): 68-75 DOI: 10.1016/j.catena.2006.10.006

Merheb M, Moussa R, Abdallah C, Colin F, Perrin C, Baghdadi N. 2016. Hydrological response characteristics of Mediterranean catchments at different time scales: a meta-analysis. Hydrological Sciences Journal 61 (14): 2520-2539 DOI: 10.1080/02626667.2016.1140174

Moody JA, Shakesby RA, Robichaud PR, Cannon SH, Martin DA. 2013. Current research issues related to post-wildfire runoff and erosion processes. Earth-Science Reviews 122: 10-37 DOI: 10.1016/j.earscirev.2013.03.004

Moreira F, Rego FC, Ferreira PG. 2001. Temporal (1958-1995) pattern of change in a cultural landscape of northwestern Portugal : implications for fire occurrence. Landscape Ecology 16 (6): 557-567 DOI: 10.1023/A:1013130528470

Morgan RPC. 2009. Soil Erosion and Conservation. Blackwell Publishing: Oxford.

Nunes AN, Lourenço L. 2017. Increased vulnerability to wildfires and post fire hydro-geomorphic processes in Portuguese mountain regions: What has changed? Open Agriculture 2 (1): 70-82 DOI: 10.1515/opag-2017-0008

Nunes AN, de Almeida AC, Coelho COA. 2011. Impacts of land use and cover type on runoff and soil erosion in a marginal area of Portugal. Applied Geography 31 (2): 687-699 DOI: 10.1016/j.apgeog.2010.12.006

Nunes JP, Bernard-Jannin L, Rodríguez Blanco ML, Santos JM, Coelho COA, Keizer JJ. 2018a. Hydrological and erosion processes in terraced fields: observations from a humid mediterranean region in northern Portugal. Land Degradation \& Development 29 (3): 596-606 DOI: $10.1002 / \mathrm{ldr} .2550$

Nunes JP, Doerr SH, Sheridan G, Neris J, Santín C, Emelko MB, Silins U, Robichaud PR, Elliot WJ, Keizer J. 2018b. Assessing water contamination risk from vegetation fires: challenges, 
opportunities and a framework for progress. Hydrological Processes 32 (5): 687-684 DOI: 10.1002/hyp.11434

Nunes JP, Malvar M, Benali AA, Rial Rivas ME, Keizer JJ. 2016. A simple water balance model adapted for soil water repellency: Application on Portuguese burned and unburned eucalypt stands. Hydrological Processes 30: 463-478 DOI: 10.1002/hyp.10629

Nunes JP, Quintanilla PN, Santos JM, Serpa D, Carvalho-Santos C, Rocha J, Keizer JJ, Keesstra SD. 2018c. Afforestation, Subsequent Forest Fires and Provision of Hydrological Services: A ModelBased Analysis for a Mediterranean Mountainous Catchment. Land Degradation and Development 29 (3): 776-788 DOI: 10.1002/ldr.2776

Pastor AV, Nunes JP, Ciampalini R, Koopmans M, Baartman J, Huard F, Calheiros T, Le-Bissonnais Y, Keizer JJ, Raclot D. 2019. Projecting future impacts of global change including fires on soil erosion to anticipate better land management in the forests of NW Portugal. Water 11 (12): 119 DOI: $10.3390 / w 11122617$

Pausas JG, Llovet J, Anselm R, Vallejo R. 2008. Are wildfires a disaster in the Mediterranean basin? A review. International Journal of Wildland Fire 17 (6): 713-723 DOI: 10.1071/WF07151

Peña-Angulo D, Nadal-Romero E, González-Hidalgo JC, Albaladejo J, Andreu V, Bagarello V, Barhi H, Batalla RJ, Bernal S, Bienes R, et al. 2019. Spatial variability of the relationships of runoff and sediment yield with weather types throughout the Mediterranean basin. Journal of Hydrology 571 (February): 390-405 DOI: 10.1016/j.jhydrol.2019.01.059

Pereira HM, Domingos T, Vicente L, Proença V. 2009. Ecossistemas e Bem-Estar Humano: Avaliação para Portugal do Millennium Ecosystem Assessment. Escolar Editora: Lisbon.

Porto P, Walling DE, Callegari G. 2009. Investigating the effects of afforestation on soil erosion and sediment mobilisation in two small catchments in Southern Italy. Catena 79 (3): 181-188 DOI: 10.1016/j.catena.2009.01.007

Prats SA, González-Pelayo Ó, Silva FC, Bokhorst KJ, Baartman JEM, Keizer JJ. 2019. Post-fire soil erosion mitigation at the scale of swales using forest logging residues at a reduced application rate. Earth Surface Processes and Landforms 44 (14): 2837-2848 DOI: 10.1002/esp.4711

Prats SA, Wagenbrenner JW, Martins MAS, Malvar MC, Keizer JJ. 2016. Mid-term and scaling effects of forest residue mulching on post-fire runoff and soil erosion. Science of the Total Environment 573: 1242-1254 DOI: 10.1016/j.scitotenv.2016.04.064

Rasmussen PP, Gray JR, Glysson GD, Ziegler AC. 2009. Guidelines and procedures for computing time-series suspended-sediment concentrations and loads from in-stream turbidity-sensor and streamflow data: Techniques and Methods 3-C4. In Book 3, Applications of Hydraulics Section C, Sediment and Erosion TechniquesUS Geological Survey; 53. Available at: http://pubs.usgs.gov/tm/tm3c4/

Rodríguez-Blanco ML, Taboada-Castro MM, Taboada-Castro MT. 2010. Factors controlling hydrosedimentary response during runoff events in a rural catchment in the humid Spanish zone. Catena 82 (3): 206-217 DOI: 10.1016/j.catena.2010.06.007

Rodríguez-Blanco ML, Taboada-Castro MM, Taboada-Castro MT. 2013. Linking the field to the stream: Soil erosion and sediment yield in a rural catchment, NW Spain. Catena 102: 74-81 DOI: $10.1016 /$ j.catena.2010.09.003

Rodríguez-Blanco ML, Taboada-Castro MM, Taboada-Castro MT. 2019. An overview of patterns and dynamics of suspended sediment transport in an agroforest headwater system in humid climate: Results from a long-term monitoring. Science of the Total Environment 648: 33-43 
DOI: 10.1016/j.scitotenv.2018.08.118

Rodriguez-Lloveras X, Buytaert W, Benito G. 2016. Land use can offset climate change induced increases in erosion in Mediterranean watersheds. Catena 143: 244-255 DOI: 10.1016/j.catena.2016.04.012

Santos JA, Corte-Real J, Leite SM. 2005. Weather regimes and their connection to the winter rainfall in Portugal. International Journal of Climatology 25 (1): 33-50 DOI: 10.1002/joc.1101

Santos JM, Verheijen FGA, Tavares Wahren F, Wahren A, Feger K-H, Bernard-Jannin L, Rial-Rivas ME, Keizer JJ, Nunes JP. 2016. Soil water repellency dynamics in pine and eucalypt plantations in portugal - a high-resolution time series. Land Degradation and Development 27 (5): 1334-1343 DOI: $10.1002 /$ ldr.2251

Shakesby RA. 2011. Post-wildfire soil erosion in the Mediterranean: Review and future research directions. Earth-Science Reviews 105 (3-4): 71-100 DOI: 10.1016/j.earscirev.2011.01.001

Shakesby RA, Boakes DJ, Coelho COA, Gonçalves AJB, Walsh RPD. 1996. Limiting the soil degradational impacts of wildfire in pine and eucalyptus forests in Portugal. Applied Geography 16 (4): 337-355 DOI: 10.1016/0143-6228(96)00022-7

Silva V, Pereira JL, Campos I, Keizer JJ, Gonçalves F, Abrantes N. 2015. Toxicity assessment of aqueous extracts of ash from forest fires. Catena 135: 401-408 DOI:

10.1016/j.catena.2014.06.021

Simonneaux V, Cheggour A, Deschamps C, Mouillot F, Cerdan O, Le Bissonnais Y. 2015. Land use and climate change effects on soil erosion in a semi-arid mountainous watershed (High Atlas, Morocco). Journal of Arid Environments 122 (February 2016): 64-75 DOI:

10.1016/j.jaridenv.2015.06.002

Smetanová A, Le Bissonnais Y, Raclot D, Pedro Nunes J, Licciardello F, Le Bouteiller C, Latron J, Rodríguez Caballero E, Mathys N, Klotz S, et al. 2018. Temporal variability and time compression of sediment yield in small Mediterranean catchments: impacts for land and water management. Soil Use and Management 34 (3): 388-403 DOI: 10.1111/sum.12437

Stoof CR, Vervoort RW, Iwema J, Van Den Elsen E, Ferreira AJD, Ritsema CJ. 2012. Hydrological response of a small catchment burned by experimental fire. Hydrology and Earth System Sciences 16 (2): 267-285 DOI: 10.5194/hess-16-267-2012

Tavares Wahren F, Julich S, Nunes JP, Gonzalez-Pelayo O, Hawtree D, Feger KH, Keizer JJ. 2016. Combining digital soil mapping and hydrological modeling in a data scarce watershed in northcentral Portugal. Geoderma 264: 350-362 DOI: 10.1016/j.geoderma.2015.08.023

Valente F, David JS, Gash JHC. 1997. Modelling interception loss for two sparse eucalypt and pine forests in central Portugal using reformulated Rutter and Gash analytical models. Journal of Hydrology 190 (1-2): 141-162 DOI: 10.1016/S0022-1694(96)03066-1

Varela ME, Benito E, Keizer JJ. 2015. Influence of wildfire severity on soil physical degradation in two pine forest stands of NW Spain. Catena 133: 342-348 DOI: 10.1016/j.catena.2015.06.004

Verkaik I, Rieradevall M, Cooper SD, Melack JM, Dudley TL, Prat N. 2013. Fire as a disturbance in mediterranean climate streams. Hydrobiologia 719 (1): 353-382 DOI: 10.1007/s10750-013$1463-3$

Vieira DCS, Fernández C, Vega JA, Keizer JJ. 2015. Does soil burn severity affect the post-fire runoff and interrill erosion response? A review based on meta-analysis of field rainfall simulation data. Journal of Hydrology 523: 452-464 DOI: 10.1016/j.jhydrol.2015.01.071 
Wu J, Baartman JEM, Nunes JP. 2020. Comparing the impacts of wildfire and meteorological variability on hydrological and erosion responses in a Mediterranean catchment. Land Degradation \& Development: Idr.3732 DOI: 10.1002/Idr.3732 
Supplementary Material
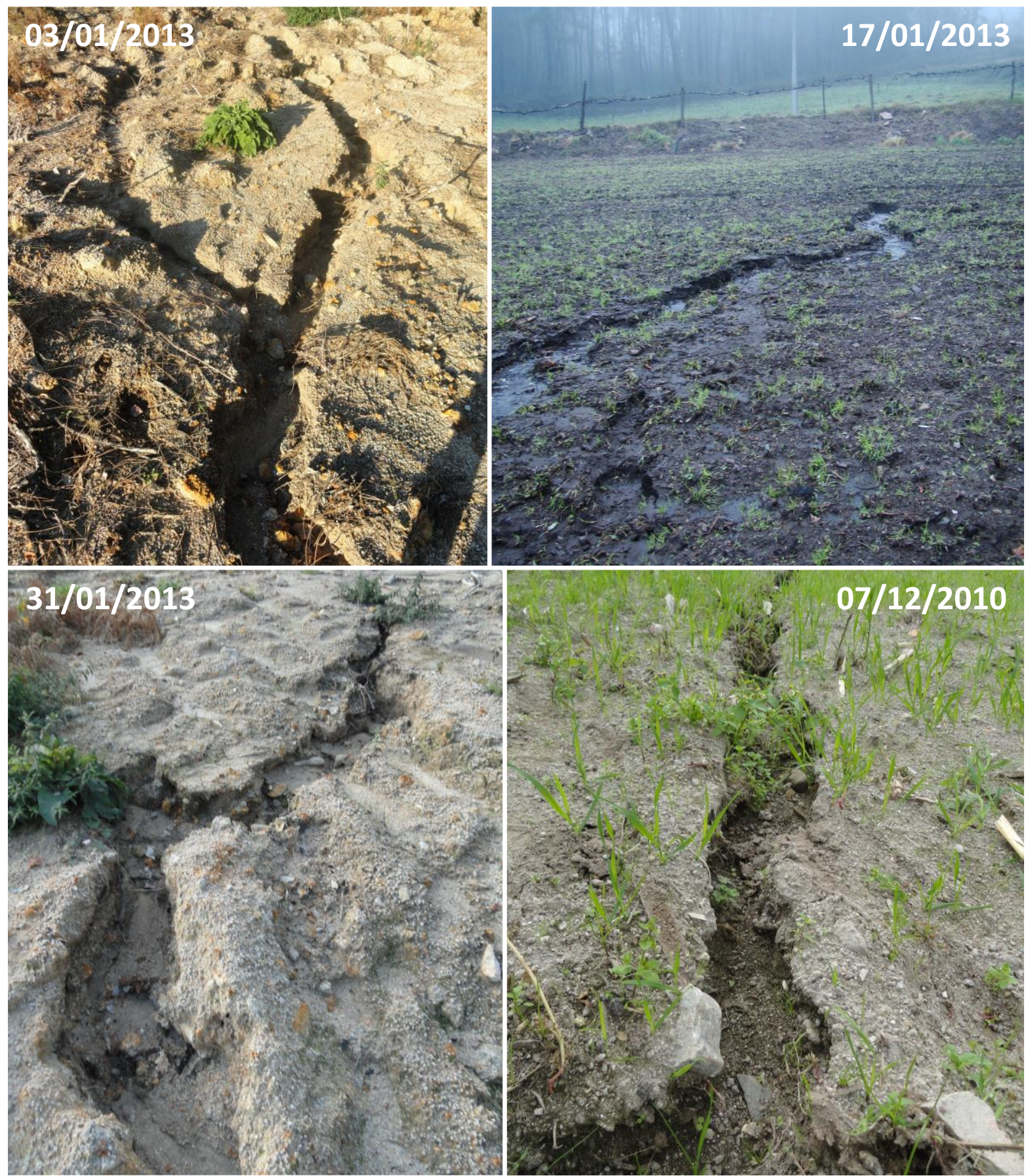

Figure S 1. Photos from rills in the burnt area (left) and agricultural fields (right) 


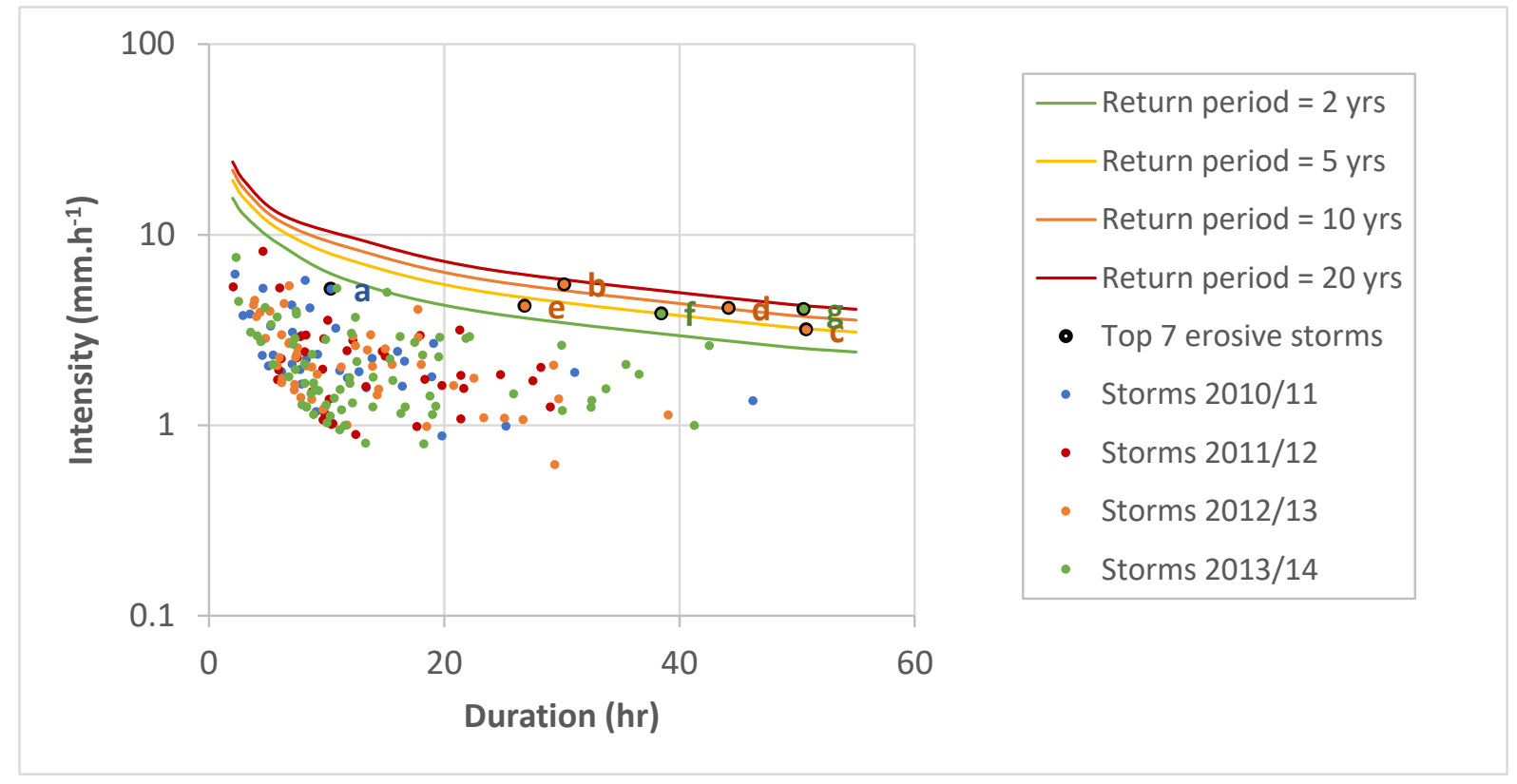

Figure S 2. Intensity-Duration-Frequency curves for rain storms in Macieira with rainfall >10 mm ( $\mathrm{Y}$ axis in logarithmic scale), with the top 7 erosive events marked (see labels in Table S 1).

Table S 1. Characteristics of the top 7 erosive events, for the parameters described in Table 1 of the manuscript.

Storm

\begin{tabular}{|c|}
\hline Return period (yr \\
\hline PPtot (mm) \\
\hline PPI30 (mm.h $\left.\mathrm{h}^{-1}\right)$ \\
\hline PPtime (hr) \\
\hline PPant \\
\hline Qtot (mm) \\
\hline Qi $\left(L_{.} \mathrm{s}^{-1}\right)$ \\
\hline $\operatorname{Qmax}\left(\right.$ L.s. $\left.^{-1}\right)$ \\
\hline Qbase \\
\hline Q/PP \\
\hline Qtime (hr) \\
\hline Syield (ton.ha-1) \\
\hline Shyst \\
\hline Sconc (g. $\left.\mathrm{L}^{-1}\right)$ \\
\hline Vfire \\
\hline Vagri \\
\hline
\end{tabular}

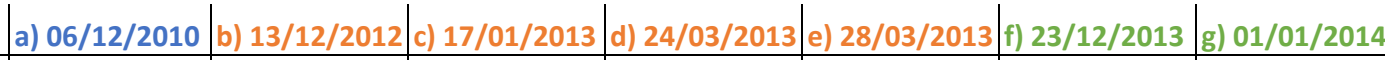

\begin{tabular}{c|c|c|c|c|c|c}
1.2 & 11.5 & 3.2 & 7.4 & 2.8 & 4.0 & 9.5 \\
53.7 & 165.4 & 161.0 & 181.8 & 113.1 & 147.7 & 205.2 \\
31.5 & 18.2 & 15.8 & 12.5 & 18.2 & 41.2 & 14.1 \\
10.4 & 30.2 & 50.8 & 44.2 & 26.9 & 38.5 & 50.6 \\
71.8 & 13.5 & 63.4 & 48.6 & 132.9 & 35.4 & 84.0 \\
44.9 & 73.6 & 95.6 & 71.9 & 96.1 & 21.2 & 139.6 \\
176.4 & 2.1 & 77.4 & 79.8 & 218.0 & 25.1 & 216.8 \\
585.3 & 884.0 & 1293.5 & 851.0 & 2530.6 & 1227.8 & 1161.2 \\
$66.5 \%$ & $44.3 \%$ & $57.8 \%$ & $52.3 \%$ & $71.6 \%$ & $47.8 \%$ & $66.4 \%$ \\
$28.0 \%$ & $24.8 \%$ & $25.1 \%$ & $18.9 \%$ & $24.1 \%$ & $7.5 \%$ & $22.9 \%$ \\
6.1 & 24.8 & 34.6 & 17.4 & 15.3 & 15.0 & 29.4 \\
0.02 & 0.06 & 0.11 & 0.05 & 0.11 & 0.04 & 0.05 \\
0.06 & 0.37 & 0.03 & 0.31 & -0.04 & 0.29 & 0.24 \\
0.05 & 0.09 & 0.12 & 0.08 & 0.12 & 0.19 & 0.04 \\
-0.05 & 0.11 & 0.18 & 0.14 & 0.13 & 0.04 & 0.04 \\
0.59 & 0.69 & 0.68 & 0.73 & 0.73 & 0.70 & 0.71
\end{tabular}




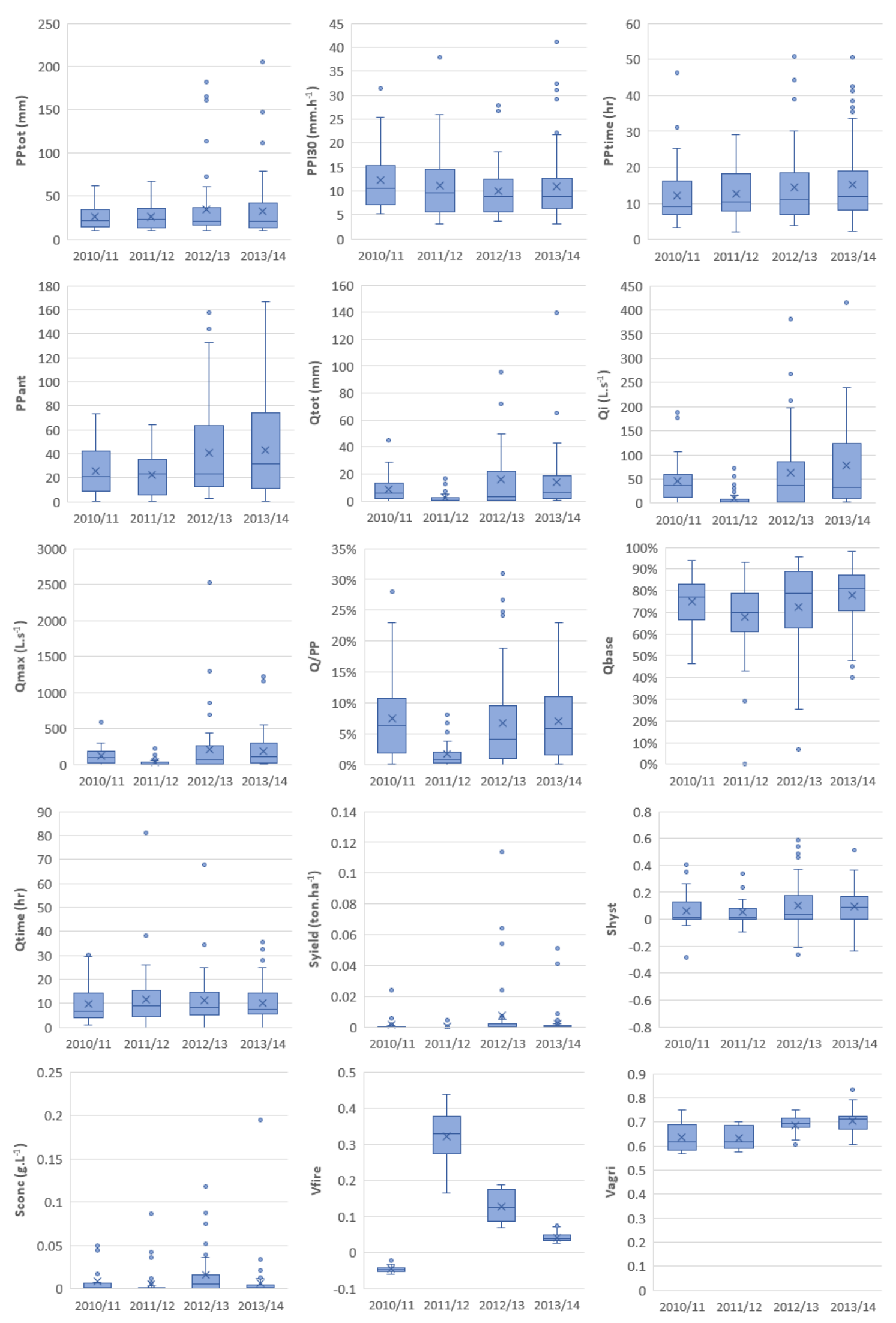

Figure S 3. Box-plots representing rainfall, streamflow, sediment and vegetation parameters per event and per year, following the parameters described in Table 1 of the manuscript. 